\title{
MINERAL-RESOURCE MAP OF THE PETERSBURG QUADRANGLE AND PARTS OF THE PORT ALEXANDER, SITKA, AND SUMDUM QUADRANGLES, SOUTHEASTERN ALASKA
}

\author{
By David A. Brew ${ }^{1}$, Donald J. Grybeck ${ }^{2}$, John B. Cathrall ${ }^{3}$, Susan M. Karl ${ }^{2}$, Richard B. Koch ${ }^{1}$, \\ David F. Barnes ${ }^{1}$, Rainer J. Newberry ${ }^{4}$, Andrew Griscom ${ }^{1}$, and Henry C. Berg ${ }^{5}$
}

\section{INTRODUCTION}

The Petersburg project region covers about 16,300 $\mathrm{km}^{2}$ and includes all of the Petersburg, about one-third of the Port Alexander, a small part of the Sitka, and about one-tenth of the Sumdum 1:250,000-scale quadrangles. The region is located in south-central southeastern Alaska and includes parts of the (from west to east) Chatham Trough, Prince of Wales Mountains, Kupreanof Lowland, Coastal Foothills, and Boundary Ranges physiographic divisions of Wahrhaftig (1965). Two towns, Petersburg and Wrangell, and two villages, Kake and Point Baker, are in the region.

The region contains three mines and a wide variety of metallic mineral occurrences (Grybeck and others, 1984). One mine produced barite, one gold, and the other garnet. The region has long attracted the attention of prospectors and mineral exploration companies.

This map and text report the results of a mineralresource-assessment study done during the period 1978 to 1982. The resource terminology used here is that of the U.S. Bureau of Mines and U.S. Geological Survey (1980; see Appendix A). As described below, a multidisciplinary team working in the field and office identified five mineral-resource tracts containing identified resources and other attributes that indicate a high probability for the occurrence of economic mineral deposits. The team also identified eight other tracts that have quantified undiscovered resources and other attributes that indicate a lesser probability for economic deposits. Unquantified undiscovered resources are believed to be present in 15 other tracts; three tracts have only geophysical anomalies that may have mineral-resource significance. Altogether, 31 tracts are shown on the map and described below. Several of the tracts overlap because they are defined by separate criteria or because different types of deposits are interpreted to be present.

In addition to the resources inferred to be present in the 31 tracts, other undiscovered mineral resources may

\footnotetext{
1 USGS, Menlo Park, CA 94025

2USGS, Anchorage, AK 99508

3 USGS, Denver, CO 80225

4USGS and University of Alaska, Fairbanks, AK 99775

$5_{115}$ Malvern Avenue, Fullerton, CA 92632
}

be present in other areas, contained in types of densits not yet known to exist in the region, and in undiscovered placer gold deposits. Known nonmetallic resources of marble, fluorite, and garnet are also present.

This project region (Brew and others, 19\&4) is perhaps the single most geologically varied and complicated 1:250,000-scale map area in the entire United States. The stratigraphic section ranges from Ordovician through Neogene and includes a wide variety of rock types from island-arc-related graptolite-bearing turbidites to postglacial tholeiitic basalt flows. Seven intrusive igneous episodes are represented; they range from 110-Ma Alaskan-type concentrically zoned maficultramafic plutons to $15-\mathrm{Ma}$ granite and rhyolite plugs. Seven post-Early Cretaceous metamorphic events are recorded: (1) regional dynamothermal metamorphism that affected the Lower Cretaceous sedimentary rocks; (2) low-pressure, thermal contact-metamorphic aureoles associated with the discontinuous belt of $110-\mathrm{Ma}$ ultramafic bodies; (3) a local low-pressure thermal event adjacent to 100-Ma intrusions; (4) a Late Cretaceous, local to regional, low- to intermediate-pressure event associated with the discontinuous belt of $9{ }^{5}-\mathrm{Ma}$ intrusions; (5) a latest Cretaceous and early Tertiary regional Barrovian metamorphism associated with a narrow belt of 70 - to 55-Ma intrusions; (6) a reçional low-pressure thermal event associated with a broad belt of 50-Ma intrusions; and (7) a local low-pressure th ${ }^{-r m a l}$ event associated with 20-Ma plutons. Relatively simple, fault-dominated structures complicate the outcrop areas of older Paleozoic rocks; in contrast, adjacent but not overlying younger Paleozoic and Mesozoic strata have been repeatedly involved in southwest-vergent fording. The western boundary of the project region is the major Chatham Strait fault, that has $100 \mathrm{~km}$ to $180 \mathrm{~km}$ of rightlateral separation (Ovenshine and Brew, 1972; Sonnevil, 1981; Hudson and others, 1982). It is the sor them continuation of the Denali-Shakwak system and is here completely concealed by Chatham Strait. The majcr and enigmatic Coast Range megalineament (Brew and Ford, 1978) cuts through the northeastern corner of the region, close to the deformed and metamorphosed eastern margin of an Upper Jurassic to Lower Cretaceous flysch and volcanic overlap sequence. 


\section{ASSESSMENT METHOD}

The mineral-resource assessment was done by what is referred to technically as an "expert panel" made up of regional geologists, economic geologists, geochemists, and a geophysicist, all of whom had participated in 44 person-months of fieldwork during 1978 to 1982 . This fieldwork followed about 48 person-months of regional geologic mapping and geophysical studies done by other U.S. Geological Survey parties from 1942 to 1971 . The final assessment was done by the panel as a whole; the process involved systematic review and discussion of the different data discussed below; followed by consensus on the boundaries of the different mineral-resource tracts, on the types of deposits interpreted to be present, and on the quantified resources (if any) present in the 31 tracts shown on the map.

The expert panel utilized the following basic information in their interpretations and syntheses: bedrock geology (Brew and others, 1984); economic geology (Grybeck and others, 1984); bedrock geochemistry (Karl and others, 1985; S.M. Karl and R.D. Koch, unpub. data, 1989); stream-sediment and pannedconcentrate geo-chemistry (Cathrall and others, 1983aw; Tripp and Cathrall, 1984); aeromagnetic survey (U.S. Geological Survey, 1979b); a high-flight-level aeroradioactivity survey (U.S. Geological Survey, 1979a); gravity survey (Barnes, 1972a-c; Bames and others, 1972a,b; Barnes and others, 1975); and telegeology (Le Compte, 1981). In addition, a bibliography was prepared (Burrell and others, 1982), a low-flight-level aeroradioactivity survey was made of most of the region, and specific studies were made of selected mineral deposits and occurrences. Specific studies of several uranium occurrences (Dickinson, 1979a,b; Dickinson and Campbell, 1983, 1984; Dickinson and Pierson, 1989; Dickinson and Vuletich, in press) and of an important belt of sulfide occurrences (Berg and Grybeck, 1980; Berg, 1981) were also used in the synthesis.

Various interpretative maps and reports based on the above and other sources were prepared by the panel members for use in the final assessment. The first two items prepared were (1) a list of 16 different types of mineral deposits identified as being already known in the project area or being geologically permissible, and (2) an interpretation of the geology that showed different parts of the region considered to be geologically permissible for those 16 types of mineral deposits. Insofar as possible, these and other similar steps were done without using other types of information; in other words, in the case of the permissive geology map, such things as known metallic mineral occurrences and geochemistry were not considered in delineating host-rock units permissive for a specific type of deposit. The intent was to extract as much permissive information as possible from each source before evaluating how the different interpretations interacted.

The original list of deposits was subsequently revised to 17 by (1) eliminating deposit types that were decided not likely to be present, (2) adding some deposit types not originally considered to be present, and (3) revising the types to correspond to the classification used by Nokleberg and others $(1987,1988)$. This latter classification is based mainly on the mineral-deposit models developed by Erickson (1982), Cox (1983a, b), and Cox and Singer (1986). The deposit types used in the assessment are as follows: (1) gabbroic $\mathrm{Ni}-\mathrm{Cu}$ deposit, (2) zoned mafic-ultramafic $\mathrm{Cr}-\mathrm{Pt}( \pm \mathrm{Cu}, \mathrm{Ni}, \mathrm{Co}, \mathrm{Ti}, \mathrm{Fe}$ ) deposit, (3) carbonatite deposit, (4) Sn greisen, Sn vein, $\mathrm{Sn}$ replacement, and $\mathrm{Sn}$ skarn deposits, (5) $\mathrm{Cu}-\mathrm{Pb}-\mathrm{Zn}$ ( \pm $\mathrm{Au}, \mathrm{Ag}$ ), W, and $\mathrm{Fe}$ ( $\pm \mathrm{Au}$ ) skam deposits, (6) porphyry $\mathrm{Cu}-\mathrm{Mo}$, porphyry $\mathrm{Cu}$, and porphyry Mo deposits, (7) polymetallic vein deposits, (8) felsic plutonic U deposit, (9) Cyprus massive sulfide deposit, (10), Besshi massive sulfide deposit, (11) epithermal vein deposit, (12) Kuroko massive sulfide deposit, (13) sandstone $U$ deposit, (14) sedimentary exhalative $\mathrm{Zn}-\mathrm{Pb}$ deposit, (15) bedded barite deposit, (16) low-sulfide Au-quartz vein deposit (abbrev. to Au-quartz vein deposit), and (17) metamorphosed sulfide deposit. These deposit types are are described briefly in Appendix B, which is reprinted with minor modifications from Nokleberg and others (1988).

Cluster analysis and mineral-deposit-geochemicalsignature information were applied to the data from 1,449 stream-sediment, 1,430 panned-concentrate, and 442 pebble samples in order to generate interpretative maps showing various elemental ratios, relative abundances of elements expected in different types of deposits, and the relations of these derivative measures to anomalous concentrations of single elements in different parts of the region. Similarly, the geochemical data from 6,974 bedrock samples were interpreted to show both anomalous concentrations above expected background values and anomalous concentrations in different parts of the region (S.M. Karl and R.D. Koch, unpub. data, 1989).

Geophysical studies included aeromagnetic and gravity surveys and interpretation. The aeromagnetic survey was interpreted in preliminary fashion, and a map showing significant anomalies and gradients, together with some suggestions about the origin of the different anomalies, was prepared for use in the final assessment. The gravity survey data were interpreted in detail and a new Bouguer gravity map prepared for the region (Barnes and others, 1989).

The expert panel used over 150 separate maps in a stacking, comparing, and discussion process to assess the mineral resources of the region. After all the data had been reviewed and discussed, the tracts that had mineralresource significance were delineated; the features used to delineate the tracts are given in the following section that discusses the individual tracts. The 31 tracts were classified into five ranks, based on the criteria given immediately below. All of the tracts, except for those in rank V (tracts based on geophysical evidence alone), have geology that is permissive for a specific mineraldeposit type. The criteria for each rank are:

I. A mine (with or without recorded production); significant stream-sediment-, panned-concentrate-, and 
(or) bedrock-geochemical anomalies; and, in some cases, significant geophysical anomalies.

II. One or more prospects or metallic-mineral occurrences; significant stream-sediment-, pannedconcentrate-, and (or) bedrock-geochemical anomalies; and, in some cases, significant geophysical anomalies.

III. Minor metallic-mineral occurrences, significant stream-sediment-, panned-concentrate-, and (or) bedrockgeochemical anomalies; and, in some cases, significant geophysical anomalies.

IV. Permissive geology; some bedrock geochemical anomalies.

\section{A significant geophysical anomaly.}

In addition to the resources contained in these five ranks, undiscovered deposits of unsuspected types may be present in the project region. The possibility of placer gold resources is considered very unlikely, given the glacial history of the region and the intensity of early gold prospecting. Resources of sand, gravel, limestone, dimension stone, and garnet are present, but we did not evaluate them. Preliminary versions of the detailed information given in this report have been presented previously (Brew and others, 1987).

\section{DESCRIPTIONS OF MINERAL- RESOURCE TRACTS}

The 31 tracts interpreted to have mineral resources are described individually below. With the exception of references to mines and prospects, all of the background material (such as that for stream-sediment geochemistry) is that listed in the previous section. Information concerning these individual areas is summarized synoptically in table 1 (on the map sheet).

These points should be kept in mind when evaluating the information describing the 31 tracts: (1) In places where different tracts of the same or different rank overlap, the geochemical anomalies are generally discussed for the higher ranked tracts first; if exactly the same geochemical information is used as criteria for overlapping tracts, that fact is stated. (2) In evaluating either identified or undiscovered resources as "marginally economic" or "subeconomic", we base that evaluation on present exploration, available geologic information, and metal price conditions; it does not exclude the possibility that economic resources are present, but are as yet unrecognized, nor does it exclude the possibility that economic conditions or processing technology development may make a deposit economically viable in the future. (3) In the resource assessment part of each description a subjective estimate of our own certainty in making that resource assessment is given; words such as "high probability of occurrence" indicate that we are about 90 percent confident that our assessment is accurate, "moderate probability of occurrence" indicates that we are about 70 percent confident, and "low probability of occurrence" indicates we are about 50 percent confident. These subjective estimates of our certainty should not be misinterpreted as any typ? of probabilistic estimate of the frequency, size, or grad : of the deposits that would contain the resources we have assessed as being present, nor are they an estimate of the probability of actually discovering a deposit. (4) $\mathrm{T}$ are some discrepancies between the commodities discussed in individual tracts and the commodities shown on the map as present in individually numbered mines, prospects, and occurrences. This is because the latter are taken directly from Grybeck and others (1984) wit'out modification and they are from an earlier data base.

The expert panel originally concluded that the level of available information was such that probabilistic analysis of the occurrence of undiscovered resources in the 31 mineral-resource tracts was not appropriate. The conclusion was later reexamined in regard to the rank I tracts, and probabilistic assessments have been prepred for tract numbers 1 and 2 . The numbers of deposits estimated to be present are based on subjective evaluation of all of the available information. The other tracts in rank I do not have such assessments for the reasons given in the individual tract descriptions.

Some further explanations for the tract discussions are the following: The mineral deposit types referre.t to in the following descriptions of the individual mineralresource tracts are explained briefly in Appendix B The terms "high", "moderate", "low", and "none" are uset to describe the level of past exploration activity: "high" indicates extensive drilling, surface excavation, geol 'gic mapping, and geochemical sampling; "moderate" m?ans less extensive activities of the same kind; "low" m?ans geologic mapping and geochemical sampling. Appendix $C$ explains the abbreviations used in the text and or the map. 
MINERAL-RESOURCE TRACT NO. 1

Rank: $\quad$ I

Tract name and location: Duncan Canal fault zone; Kupreanof, Zarembo, and Etolin Islands.

Tract boundaries based on distribution of: Triassic and Mesozoic(?) rocks and stream-sediment geochemical anomalies.

Mineral deposits

Type(s) of deposits known or Inferred to be present: Kuroko massive sulfide, bedded barite.

Commodities of interest: $\mathrm{Pb}, \mathrm{Zn}, \mathrm{Cu}, \mathrm{Ba}, \mathrm{Ag}, \mathrm{Au}$.

Name(s) of mines and(or) prospects (Locality numbers from Grybeck and others, 1984): Castle Irland mine (31), Taylor Creek (13), Silver Star (15), St. John Harbor (59), Round Point (65) prospects occurrences (29), (30), (63), (64).

Production: Castle Island mine: estimated 750,000 tons barite, 1968-73.

Quantified resources: See below.

Level of past exploration activity: Moderate to high.

Geophysics

Aeromagnetic features: Sharp-sided high anomaly near Harveys Lake; strong high in tract 27.

Gravity features: Large low in central part of zone.

Aeroradioactivity features: None present.

Telegeologic features: Dense linears mark Duncan Canal fault zone..

Exploration geochemistry

Stream-sediment and(or) panned-concentrate geochemical anomalies: Scattered $\mathrm{Cu}, \mathrm{Pb}, \mathrm{Ba}, \mathrm{Mo}$, and $\mathrm{W}^{r}$ throughout belt; see also tracts 4 and 6 .

Bedrock geochemical anomalies: Strong $\mathrm{Ba}, \mathrm{Zn}, \mathrm{Pb}, \mathrm{Cu}$; some $\mathrm{Mo}, \mathrm{Cr}, \mathrm{Co}, \mathrm{As}$; see also tracts 4 and 6.

Resource assessment

Classification of resources (see Appendix A): Undiscovered hypothetical resources; marginally economic $"$ economic; quantified high probability of occurrence. 
Probabilistlc assessment:

1. Total number of undiscovered deposits of either type ${ }^{1}$

Percent probability

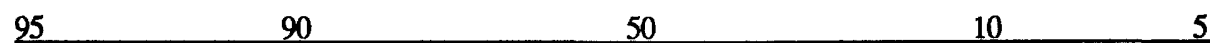

$\begin{array}{lllll}0 & 2 & 4 & 6 & 8\end{array}$

Probabilistic assessment-Continued

2. Estimated tonnage and grade of deposits (Cox and Singer, 1986)

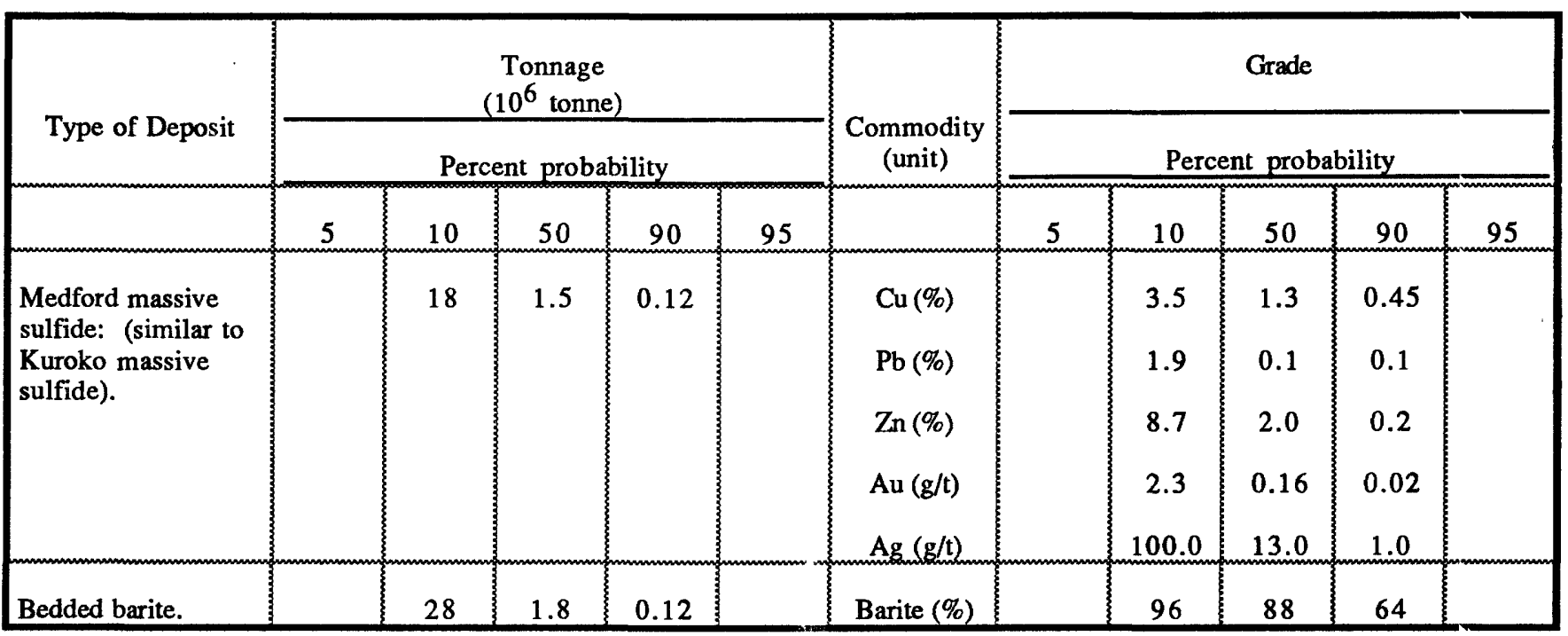

${ }^{1}$ Probability of undiscovered deposits estimated on the basis of datä on known deposits, dimensions of known deposits, ard local geochemistry and geophysics. The probability that deposits of given tonnage and grade occur in the area is estimatec' using statistical data assembled in geologically similar areas (Cox nnd Singer, 1986).

Discussion: Includes all of tracts 4 and 6 and parts of tracts 14, 19, 28, 29, 30 and 31; disruption in fault zone may complicate exploration.

References: Wright and Wright, 1905; Burchard, 1914; Buddington, 1923, 1925; Buddington and Chapin, 1929; Kerns 1950; Berg and Grybeck, 1980; Karl and others, 1980; Berg, 1981; Grybeck and others, 1984. 
MINERAL-RESOURCE TRACT NO. 2

Rank:

I

Tract name and location: Groundhog Basin; mainland northeast of Wrangell

Tract boundaries based on distribution of: Tertiary granite and rhyolite and small linear aeromagnetic anomalies.

Mineral deposits

Type(s) of deposits known or inferred to be present: Replacement Sn, porphyry Mo(?).

Commodities of interest: $\mathrm{Sn}, \mathrm{Mo}(?)$.

Name(s) of mines and(or) prospects (Locality numbers from Grybeck and others, 1984): Camp Six/Whistlepig (43) prospect.

Production: None reported.

Quantified resources: See resource assessment.

Level of past exploration activity: High.

Geophysics

Aeromagnetic features: Small linear anomalies.

Gravity features: On steep gradient.

Aeroradioactivity features: None.

Telegeologic features: Strong linears of Coast Range megalineament within tract.

\section{Exploration geochemistry}

Stream-sediment and(or) panned-concentrate geochemical anomalies: Strong Sn, Mo, W; see tracts 3 and 15.

Bedrock geochemical anomalies: Abundant $\mathrm{Sn}, \mathrm{Cu}, \mathrm{Pb}, \mathrm{Zn}$; some $\mathrm{Mo}, \mathrm{Ni}, \mathrm{Cr}, \mathrm{Co}$; see tracts 3 and 15 .

\section{Resource assessment}

Classification of resources (see Appendix A): Undiscovered unquantified hypothetical resources of Sn; economic to marginally economic; moderate probability of occurrence.

Probabilistic assessment:

1. Total number of undiscovered ${ }^{1} S_{n}$ deposits $^{2}$

Percent probability

$\begin{array}{llllll}95 & 90 & 50 & 10 & 5 \\ 1 & 1 & 2 & 4 & 4\end{array}$


Probabilistic assessment-Continued

2. Estimated tonnage and grade of deposits (Cox and Singer, 1986)

\begin{tabular}{|c|c|c|c|c|c|c|c|c|c|c|c|}
\hline \multirow{3}{*}{ Type of Deposit } & & & $\begin{array}{l}\text { onną } \\
6 \text { ton }\end{array}$ & & & \multirow{3}{*}{$\begin{array}{l}\text { Commodity } \\
\text { (unit) }\end{array}$} & \multicolumn{5}{|c|}{ Grade } \\
\hline & \multicolumn{5}{|c|}{ Percent probability } & & \multicolumn{5}{|c|}{ Percent probability } \\
\hline & 5 & 10 & 50 & 90 & 95 & & 5 & 10 & 50 & 90 & 95 \\
\hline Replacement tin. & & 27 & 5.2 & 1.0 & & $\operatorname{Sn}(\%)$ & & 1.2 & 0.8 & 0.56 & \\
\hline
\end{tabular}

1 "Undiscovered" here includes previously unrecognized $\mathrm{Sn}$ deposit approximately coincident with recognized base-met'l deposit (see tract 3).

2 Probability of undiscovered deposits estimated on the basis of data on known deposits, dimensions of known deposits. and local geochemistry and geophysics. The probability that deposits of given tonnage and grade occur in the area is estim?ted using statistical data assembled in geologically similar areas (Cox and Singer, 1986).

Discussion: Included entirely in tracts 3 and 15; recent research (Newberry and Brew, 1989) indicates that this is a Sn-rich porphyry system.

References: Wright and Wright, 1905, 1908; Chapin, 1918; Buddington, 1923; Gault and others, 1953; Grybeck and others, 1984; Newberry and Brew, 1989. 
Rank: I

Tract name and location: Groundhog Basin belt; mainland northeast of Wrangell.

Tract boundaries based on distribution of: Tertiary granites and rhyolites to northeast; mixed pelitic and intermediate-volcanic schists; and bedrock and stream-sediment geochemical anomalies.

Mineral deposits

Type(s) of deposits known or inferred to be present: Replacement Sn; metamorphosed massive sulfide(?).

Commodities of interest: $\mathrm{Pb}, \mathrm{Zn}, \mathrm{Sn}, \mathrm{Ba}, \mathrm{Ag}, \mathrm{Au}$.

Name(s) of mines and(or) prospects (Locality numbers from Grybeck and others, 1984): Lake (40), Groundhog Basin (42), Glacier Basin (44), and Berg Basin (45) prospects.

Production: None reported.

Quantified resources: Groundhog Basin: several hundred thousand tons of $8 \% \mathrm{Zn}, 1.5 \% \mathrm{~Pb}, 51.4 \mathrm{~g} / \mathrm{T} \mathrm{Ag}$; Glacier Basin: many hundred thousand tons of $1.6 \% \mathrm{Zn}$ and $0.1 \% \mathrm{~Pb}$ (Gault and others, 1953).

Level of past exploration activity: Moderate to high.

\section{Geophysics}

Aeromagnetic features: On west flank of major, steep regiore? gradient; see tract 2.

Gravity features: Northern part on steep gradient, southern on "platform".

Aeroradioactivity features: None observed.

Telegeologic features: Strong linears of Coast Range megali. zment within tract.

Exploration geochemistry

Stream-sediment and(or) panned-concentrate geochemicin" anomalies: $\mathrm{Pb}$ at south end of tract; Ba at north end; see also tracts 2 and 15 .

Bedrock geochemical anomalies: Strong $\mathrm{Zn}, \mathrm{Ba}, \mathrm{Co}, \mathrm{Ni}, \mathrm{Cr}$; ome $\mathrm{Mo}, \mathrm{Pb}, \mathrm{Cu}$; see also tracts 2 and 15 .

Resource assessment

Classification of resources (see Appendix A): At Groundhog Basin (42) identified indicated $\mathrm{Zn}, \mathrm{Pb}, \mathrm{Sn}, \mathrm{Ag}$ resources; marginally economic or economic; :here and elsewhere undiscovered hypothetical $\mathrm{Zn}, \mathrm{Pb}$, $\mathrm{Sn}$, Ag resources; unquantified; marginally es..nomic; high probability of occurrence.

Probabilistic assessment: None; lack of a consistent pattern of jedrock geochemical anomalies and uncertainty as tc exactly what type (or how many types) of dep. sits are likely to be present.

Discussion: Includes all of tracts 2 and 15 and south end of tract 1\%; recent research (Newberry and Brew, 1989) indicates that the massive stratiform sulfide bodies are in , sart low-pressure, moderate-temperature, Sn-rich replacement deposits.

References: Wright and Wright, 1905, 1908; Chapin, 1918; Buddington, 1923; Gault and others, 1953; Karl and others, 1980; Grybeck and others, 1984; Newberry and Brew, 1989. 
MINERAL-RESOURCE TRACT NO. 4

Rank: $\quad$ I

Tract name and location: Woewodski Island and part of Kupreanof Island.

Tract boundaries based on distribution of: Stream-sediment and bedrock geochemical anomalies and aeromagnetic anomaly.

Mineral deposits

Type(s) of deposits known or inferred to be present: Au-quartz vein.

Commodities of interest: $\mathrm{Au}, \mathrm{Ag}$.

Name(s) of mines and(or) prospects (Locality numbers from Grybeck and others, 1984): Maid of Mexico (35) and Hattie mines (37); Helen S. (33) and Harvey Creek (34) prospects.

Production: Maid of Mexico mine: estimate greater than $100 \mathrm{oz}$. of $\mathrm{Au}$ and $\mathrm{Ag}$ in 1930's.

Quantified resources: None present.

Level of past exploration activity: High to moderate.

Geophysics

Aeromagnetic features: Small, sharp-sided, high anomaly near Harveys Lake may be small concealed pluton.

Gravity features: On south end of large Duncan Canal low; see tract 1.

Aeroradioactivity features: None observed.

Telegeologic features: Dense linears mark Duncan Canal faul: zone.

\section{Expleration geochemistry}

Stream-sediment and(or) panned-concentrate geochemical anomalies: Au in stream-sediment samples.

Bedrock geochemical anomalies: $\mathrm{No} \mathrm{Ba}$ although it is in Ba-rich tract (see tract 1); scattered $\mathrm{Au}, \mathrm{Ag}, \mathrm{Cu}, \mathrm{Pb}, \mathrm{Zn}$; minor $\mathrm{Co}, \mathrm{Cr}, \mathrm{Ni}, \mathrm{Mo}$.

\section{Resource assessment}

Classification of resources (see Appendix A): Undiscovered hypothetical $\mathrm{Au}$ and $\mathrm{Ag}$ resources; marginally economic; unquantified; high probability of occurrence.

Probabilistic assessment: None; tract is small and relatively well explored.

Discussion: Entirely within tract 1; entirely within Duncan Canal fault zone; southwest one-third is less attractive than Woewodski Island because fewer geochemical anomalies are there.

References: Wright and Wright, 1905, 1908; Buddington, 1923; Berg and Grybeck, 1980; Karl and others, 1980; Grybeck and others, 1984. 
Rank: I

Tract name and location: Northern Prince of Wales Island (Shakan Bay).

Tract boundaries based on distribution of: Northern Prince of Wales Island pluton and adjacent homfelsed p:litic and semipelitic rocks and stream-sediment and bedrock geochemical anomalies.

Mineral deposits

Type(s) of deposits known or inferred to be present: Porphyry Cu-Mo.

Commodities of interest: $\mathrm{Mo}, \mathrm{Cu}(?)$.

Name(s) of mines and(or) prospects (Locality numbers from Grybeck and others, 1984): Dry Pass (50), Shakan mine prospect (52).

Production: None reported.

Quantified resources: Shakan mine prospect: $10,000-20,000$ tons of about $1.5 \% \mathrm{MoS}_{2}$ (Smith, 1942).

Level of past exploration activity: Low to moderate.

\section{Geophysics}

Aeromagnetic features: Large high anomaly associated with northern Prince of Wales Island plutons.

Gravity features: Large low associated with above plutons.

Aeroradioactivity features: Large high associated with above plutons.

Telegeologic features: Large arcuate linear feature immediately west of tract.

Exploration geochemistry

Stream-sediment and(or) panned-concentrate geochemical anomalies: Minor scattered Mo, W; same as tracts 8 and 16.

Bedrock geochemical anomalies: Minor scattered $\mathrm{Mo}, \mathrm{Cu}, \mathrm{Bi}$; same as tracts 8 and 16 .

Resource assessment

Classification of resources (see Appendix A): At Shakan (52) identified inferred Mo resources; there and elsewhere undiscovered hypothetical Mo resources; marginally economic; unquantified; moderat : probability of occurrence.

Probabilistic assessment: None; although the tract is large and the one known deposit has inferred resources, nn consistent pattern of supporting bedrock or stream-sediment geochemical anomalies is present.

Discussion: Coincident with tract 8; coincident in part with tract 16.

References: Chapin, 1918; Smith, 1942; Twenhofel and others, 1946; Grybeck and others, 1984. 
MINERAL-RESOURCE TRACT NO. 6

Rank: II

Tract name and iocation: Kupreanof Mountain, Kupreanof Island

Tract boundaries based on distribution of: Mesozoic volcanic rocks and bedrock geochemical anomalies.

Mineral deposits

Type(s) of deposits known or inferred to be present: $\mathrm{Cu}-\mathrm{Zn}-\mathrm{Pb}$ skarn or Cyprus massive sulfide.

Commodities of interest: $\mathrm{Cu}, \mathrm{Pb}, \mathrm{Zn}$.

Name(s) of mines and(or) prospects (Locality numbers from Grybeck and others, 1984): Northern Copper Company prospect (12).

Production: None reported.

Quantified resources: None reported.

Level of past exploration activity: Moderate to high.

\section{Geophrsics}

Aeromagnetic features: None present

Gravity features: North of the large Duncan Canal low.

Aeroradioactivity features: None observed.

Telegeologic features: Linears of Duncan Canal fault zone are east of tract.

Expleration geochemistry

Stream-sediment and(or) panned-concentrate geochemical anomalies: None.

Bedrock geochemical anomalies: $\mathrm{Zn}, \mathrm{Pb}, \mathrm{Cu}$; minor $\mathrm{Co}, \mathrm{Ag}$.

Resource assessment

Classification of resources (see Appendix A): Undiscovered speculative $\mathrm{Cu}, \mathrm{Pb}, \mathrm{Zn}$ resources; subeconomic; unquantified; moderate probability of occurrence.

Discussion: Included entirely within tract 1.

References: Wright and Wright, 1908; Buddington, 1923; Twenhofel and others, 1946; Karl and others, 1980; Grybeck and others, 1984. 
MINERAL-RESOURCE TRACT NO. 7

Rank: II

Tract name and location: Salmon Bay; Prince of Wales Island.

Tract boundaries based on distribution of: Stream-sediment and bedrock geochemical anomalies.

Mineral deposits

Type(s) of deposits known or inferred to be present: Uncertain: felsic plutonic $U$ or carbonatite.

Commodities of interest: $\mathrm{REE}, \mathrm{Th}, \mathrm{U}, \mathrm{Cu}, \mathrm{Pb}, \mathrm{Zn}, \mathrm{Mo}$.

Name(s) of mines and(or) prospects (Locality numbers from Grybeck and others, 1984): Salmon Bay (57) occurrence.

Production: None reported.

Quantified resources: None reported.

Level of past exploration activity: Moderate.

Geophysics

Aeromagnetic features: In elongate low.

Gravity features: Rounded high to west; elongate low to east.

Aeroradioactivity features: Local small highs.

Telegeologic features: None observed.

Exploration geochemistry

Stream-sediment and(or) panned-concentrate geochemical anomalies: Scattered minor Mo, La, Nb.

Bedrock geochemical anomalies: Northern end: $\mathrm{Mo}, \mathrm{Zn}, \mathrm{Pb}$, minor $\mathrm{Au}, \mathrm{Ag}$; southern end: $\mathrm{Cu}, \mathrm{Mo}, \mathrm{Be}, \mathrm{La}, \mathrm{Nb}, \mathrm{Ba}$.

Resource assessment

Classification of resources (see Appendix A): Undiscovered speculative REE resources; subeconomic; unquantified; moderate probability of occurrence.

Discussion: Deposit type is not established.

References: White and others, 1952; Wedow and others, 1953; Houston and others, 1958; Overstreet, 1967; Eakins. 1975; Karl and others, 1980; Grybeck and others, 1984. 
Rank:

II

Tract name and location: Northern Prince of Wales Island.

Tract boundaries based on distribution of: Northern Prince of Wales Island plutons and adjacent hornfelsed pelit $=$ and semipelitic rocks and stream-sediment and bedrock geochemical anomalies.

\section{Mineral deposits}

Type(s) of deposits known or inferred to be present: Au-quartz vein.

Commodities of interest: $\mathrm{Au}, \mathrm{Ag}$.

Name(s) of mines and(or) prospects (Locality numbers from Grybeck and others, 1984): See tract 5: Dry Pass (50), Shakan Bay mine/prospect (52).

Production: None reported.

Quantified resources: None reported.

Level of past exploration activity: Low.

\section{Geophysics}

Aeromagnetic features: See tract 5: large high anomaly associated with northern Prince of Wales Island plutons.

Gravity features: See tract 5: large low associated with above plutons.

Aeroradioactivity features: See tract 5: large high associated with above plutons.

Telegeologic features: Large arcuate linear feature immediately west of tract.

\section{Exploration geochemistry}

Stream-sediment and(or) panned-concentrate geochemical anomalies: Small scattered W, Mo; same as trarts 5 and 16.

Bedrock geochemical anomalies: Minor scattered $\mathrm{Mo}, \mathrm{Cu}, \mathrm{Bi}$; same as tracts 5 and 16 .

\section{Resource assessment}

Classification of resources (see Appendix A): Undiscovered speculative $\mathrm{Au}, \mathrm{Ag}$ resources; subeconomic; unquantified; low probability of occurrence.

Discussion: Coincident with tract 5; overlaps part of tract 16 .

References: Chapin, 1918; Buddington, 1930; Smith, 1942; Twenhofel and others, 1946; Grybeck and others, 1984. 
Rank: II

Tract name and location: Thomas Bay; mainland northeast of Petersburg.

Tract boundaries based on distribution of: Bedrock geochemical anomalies.

Mineral deposits

Type(s) of deposits known or inferred to be present: Au-quartz vein.

Commodities of interest: Au, Ag.

Name(s) of mines and(or) prospects (Locality numbers from Grybeck and others, 1984): Thomas Pay (20) prospect.

Production: None reported.

Quantified resources: None reported.

Level of past exploration activity: Low.

\section{Geophrsics}

Aeromagnetic features: Near small anomaly on major regional gradient.

Gravity features: Northwest of and near small high.

Aeroradioactivity features: None observed.

Telegeologic features: Linears of Coast Range megalineament within tract.

Exploration geochemistry

Stream-sediment and(or) panned concentrate geochemical anomalies: Nqme found.

Bedrock geochemical anomalies: $\mathrm{Zn}, \mathrm{Cu}, \mathrm{Pb}, \mathrm{Mo}, \mathrm{Au}, \mathrm{Ag}, \mathrm{As}$.

\section{Resource assessment}

Classification of resources (see Appendix A): Undiscovered speculative Au and Ag resources; subeconomic; unquantified; high probability of occurrence.

Discussion: Quartz veins scattered throughout tract.

References: Buddington, 1923; Grybeck and others, 1984. 
Rank: II

Tract name and location: Southern Kuiu Island.

Tract boundaries based on distribution of: Stream-sediment geochemical anomalies.

Mineral deposits

Type(s) of deposits known or inferred to be present: Polymetallic vein.

Commodities of interest: $\mathrm{Cu}, \mathrm{Pb}, \mathrm{Zn}, \mathrm{Ag}, \mathrm{Sb}$.

Name(s) of mines and(or) prospects (Locality numbers from Grybeck and others, 1984): Point St. Albans occurrence (49).

Production: None reported.

Quantified resources: None reported.

Level of past exploration activity: Low.

\section{Geophrsics}

Aeromagnetic features: Strong to moderate, moderate- to small-sized anomalies.

Gravity features: On north side of high.

Aeroradioactivity features: None present.

Telegeologic features: Several linear and arcuate linears in tract.

Exploration geochemistry

Stream-sediment and(or) panned-concentrate geochemical anomalies: $\mathrm{Mo}, \mathrm{W}, \mathrm{Zn}$ in northern part of tract; $\mathrm{Y}, \mathrm{Nb}$ near pluton to south; Mo near Point St. Albans.

Bedrock geochemical anomalies: Weak $\mathrm{Mo}, \mathrm{Zn}, \mathrm{Cu}, \mathrm{Co}$ in rorthern part; $\mathrm{Ag}, \mathrm{As}, \mathrm{Au}, \mathrm{Bb}, \mathrm{Cu}$ in southwestern part: $\mathrm{Ag}, \mathrm{As}, \mathrm{Sb}, \mathrm{Zn}, \mathrm{Pb}, \mathrm{Cu}$ in southeastern parı of tract.

Resource assessment

Classification of resources (see Appendix A): Undiscovered speculative $\mathrm{Cu}, \mathrm{Pb}, \mathrm{Zn}, \mathrm{Ag}$ resources; subeconomic; unquantified; high probability of occurrence.

Discussion: Veins inferred to be associated with small plutons.

References: Houston and others, 1958; Berg and Cobb, 1967; K:rl and others, 1980; Grybeck and others, 1984. 
Rank:

II

Tract name and location: Blashke Islands.

Tract boundaries based on distribution of: Mafic-ultramafic rocks, aeromagnetic anomaly, and bedrock geochemical anomalies.

Mineral deposits

Type(s) of deposits known or inferred to be present: Zoned mafic-ultramafic $\mathrm{Cr}-\mathrm{Cu}-\mathrm{Ni}$.

Commodities of interest: $\cdot \mathrm{Cu}, \mathrm{Ni}, \mathrm{Cr}$.

Name(s) of mines and(or) prospects (Locality numbers from Grybeck and others, 1984): Blashke Island (58) occurrence.

Production: None reported.

Quantified resources: None reported.

Level of past exploration activity: Moderate.

\section{Geophrsics}

Aeromagnetic features: Very strong, steep-sided, small anomaly that has elongate extensions to north and south.

Gravity features: Small high.

Aeroradioactivity features: None observed.

Telegeologic features: Arcuate trends.

Exploration geochemistry

Stream-sediment and(or) panned-concentrate geochemical anomalies: $\mathrm{Ni}, \mathrm{Co}, \mathrm{Cr}$.

Bedrock geochemical anomalies: $\mathrm{Ni}, \mathrm{Cr}, \mathrm{Co}, \mathrm{Cu}, \mathrm{Pb}$.

Resource assessment

Classification of resources (see Appendix A): Undiscovered speculative $\mathrm{Cu}, \mathrm{Ni}, \mathrm{Cr}$ resources; subeconomic; unquantified; high probability of occurrence.

Discussion: Aeromagnetic anomalies extending to north and south beneath sea may indicate concealed extensions of mafic-ultramafic rocks.

References: Kennedy and Walton, 1946; Walton, 1951, Taylor, 1967; Clark and Greenwood, 1972; Grybeck and otl srs, 1984; Himmelberg and others, 1986. 


\section{MINERAL-RESOURCE TRACT NO. 12}

Rank:

II

Tract name and location: Kane Peak; northeastern Kupreanof Island.

Tract boundaries based on distribution of: Mafic-ultramafic rocks and stream-sediment and bedrock geochemical anomalies.

\section{Mineral deposits}

Type(s) of deposits known or inferred to be present: Zoned mafic-ultramafic $\mathrm{Cr}$-Cu-Fe.

Commodities of interest: $\mathrm{Fe}, \mathrm{Cr}, \mathrm{Ni}$.

Name(s) of mines and(or) prospects (Locality numbers from Grybeck and others, 1984): Kane Peak occurrence (16).

Production: None reported.

Quantified resources: None reported.

Level of past exploration activity: Moderate.

\section{Geophysics}

Aeromagnetic features: Strong, large high.

Gravity features: Strong high.

Aeroradioactivity features: None observed.

Telegeologic features: None observed.

Exploration geochemistry

Stream-sediment and(or) panned-concentrate geochemical anomalies: $\mathrm{Co}, \mathrm{Ni}, \mathrm{Cu}$.

Bedrock geochemical anomalies: $\mathrm{Ni}, \mathrm{Cr}, \mathrm{Co}$; also $\mathrm{Cu}, \mathrm{Pb}, \mathrm{Zn}, \mathrm{Mo}$.

\section{Resource assessment}

Classification of resources (see Appendix A): Undiscovered speculative $\mathrm{Ni}, \mathrm{Cr}$ resources; subeconomic; unquantified; high probability of occurrence.

Discussion: $\mathrm{Ni}, \mathrm{Cr}$, and $\mathrm{Co}$ "anomalies are not above those expected from ultramafic rocks.

References: Walton, 1951; Taylor, 1967; Taylor and Noble, 1969; Grybeck and others, 1984. 
Rank:

II

Tract name and location: Comwallis Peninsula; northem Kuiu Island.

Tract boundaries based on distribution of: Aeromagnetic anomaly and bedrock geochemical anomalies.

Mineral deposits

Type(s) of deposits known or inferred to be present: Uncertain: bedded barite, carbonatite, or Medford massive sulfide(?).

Commodities of interest: $\mathrm{Sr}, \mathrm{Ba}, \mathrm{Pb}, \mathrm{Zn}, \mathrm{Cr}, \mathrm{Ni}$.

Name(s) of mines and(or) prospects (Locality numbers from Grybeck and others, 1984): Fossil Bluffs (3) prospect and Saginaw Bay (1), Cornwallis Point (2) and Keku Islets $(5,6)$ occurrences.

Production: None reported.

Quantified resources: None reported.

Level of past exploration activity: Moderate.

Geophysics

Aeromagnetic features: Strong, deep, large high.

Gravity features: None observed.

Aeroradioactivity Peatures: None observed.

Telegeologic features: None observed.

Exploration geochemistry

Stream-sediment and(or) panned-concentrate geochemical anomalles: $\mathrm{Pb}, \mathrm{Zn}, \mathrm{Ba}, \mathrm{Nb}$.

Bedrock geochemical anomalies: $\mathrm{Cu}, \mathrm{Zn}, \mathrm{Pb}, \mathrm{La}, \mathrm{Nb}, \mathrm{Mo}, \mathrm{Ni}, \mathrm{Cr}$.

Resource assessment

Classification of resources (see Appendix A): Undiscovered speculative $\mathrm{Cu}, \mathrm{Pb}, \mathrm{Zn}, \mathrm{Ba}, \mathrm{Sr}$ resources; subeconomic; unquantified; high probability of occurrence.

Discussion: Deposit type is not established; barite and witherite veins may be related to concealed deposits; overlens tract 20 in part.

References: Buddington, 1925; Buddington and Chapin, 1929; Smith, 1933; Twenhofel and others, 1949; Cobb, 1978; Karl and others, 1980; Grybeck and others, 1984. 
Rank:

III

Tract name and location: Southern Kupreanof and southwest Zarembo Islands.

Tract boundaries based on distribution of: Middle Tertiary felsic and intermediate volcanic rocks.

Mineral deposits

Type(s) of deposits known or inferred to be present: Polymetallic vein, epithermal vein.

Commodities of interest: $\mathrm{Cu}, \mathrm{Pb}, \mathrm{Zn}, \mathrm{Mo}, \mathrm{W}(?), \mathrm{Au}$.

Name(s) of mines and(or) prospects (Locality numbers from Grybeck and others, 1984): Kushneahin Lake (24) occurrence.

Production: None reported.

Quantified resources: None reported.

Level of past exploration activity: Moderate to high.

Geophysics

Aeromagnetic features: Various strong to moderate, moderate- to large-sized anomalies, plus an unusual circular low on southwestern Kupreanof Island.

Gravity features: Generally broad high.

Aeroradioactivity features: Local anomalies associated with felsic volcanics.

Telegeologic features: Several linears in tract.

Exploration geochemistry

Stream-sediment and(or) panned-concentrate geochemical anomalies: $\mathrm{Cu}, \mathrm{Pb}, \mathrm{Mo}, \mathrm{Sn}, \mathrm{W}, \mathrm{La}, \mathrm{Y}, \mathrm{Nb}, \mathrm{Be}$ on Kupreanof Island; $\mathrm{Mo}, \mathrm{W}, \mathrm{Pb}$, on Zarembo Island.

Bedrock geochemical anomalies: $\mathrm{Zn}, \mathrm{Cu}, \mathrm{Pb}, \mathrm{As}, \mathrm{Ag}, \mathrm{Nb}, \mathrm{Be}, \mathrm{La}, \mathrm{Mo}, \mathrm{Y}$ on Kupreanof Island; $\mathrm{Pb}, \mathrm{Zn}, \mathrm{Cu}, \mathrm{Au}, \mathrm{As}$ $\mathrm{Nb}, \mathrm{Be}, \mathrm{La}, \mathrm{Mo}, \mathrm{Sn}$ on Zarembo Island.

\section{Resource assessment}

Classification of resources (see Appendix A): Undiscovered speculative $\mathrm{Cu}, \mathrm{Pb}, \mathrm{Zn}, \mathrm{Mo}, \mathrm{Au}$ resources; subeconomic; unquantified; high probability of occurrence.

Discussion: Overlaps parts of tracts 1,19 and 28.

References: Grybeck and others, 1984. 
Rank:

III

Tract name and location: Glacier Basin; mainland northeast of Wrangell.

Tract boundaries based on distribution of: Stream-sediment geochemical anomalies and pelitic schists.

Mineral deposits

Type(s) of deposits known or inferred to be present: Au-quartz vein.

Commodities of interest: $\mathrm{Au}, \mathrm{Cu}, \mathrm{Pb}, \mathrm{Mo}$.

Name(s) of mines and(or) prospects (Locality numbers from Grybeck and others, 1984): See tracts 2 and 3.

Production: None reported.

Quantified resources: None reported.

Level of past exploration activity: Moderate.

\section{Geophysics}

Aeromagnetic features: None observed.

Gravity features: Low(?).

Aeroradioactivity features: None observed.

Telegeologic features: Linears associated with Coast Range megalineament.

\section{Exploration geochemistry}

Stream-sediment and(or) panned-concentrate geochemical anomalies: Au in southwest part of tract; ser tracts 2 and 3.

Bedrock geochemical anomalies: $\mathrm{Au}, \mathrm{Pb}, \mathrm{Cu}, \mathrm{Zn}, \mathrm{Mo}$ in southwest part of tract; $\mathrm{Pb}, \mathrm{Zn}, \mathrm{Mo}, \mathrm{Au}, \mathrm{Ag}$, $\mathrm{As}$ in northeast part of tract.

\section{Resource assessment}

Classification of resources (see Appendix A): Undiscovered speculative $\mathrm{Au}, \mathrm{Cu}, \mathrm{Pb}$ resources; subeconomic; unquantified; moderate probability of occurrence.

Discussion: Includes all of tract 2 and part of tract 3.

References: Wright and Wright, 1905, 1908; Chapin, 1918; Buddington, 1923; Gault and others, 1953; Karl and otl ars, 1980; Grybeck and others, 1984; Newberry and Brew, 1989. 
MINERAL-RESOURCE TRACT NO. 16

Rank: $\quad$ III

Tract name and location: Northern Prince of Wales Island.

Tract boundaries based on distribution of: Hornfelsed rocks adjacent to northern Prince of Wales Island plutin.

Mineral deposits

Type(s) of deposits known or inferred to be present: $\mathrm{Cu}-\mathrm{Zn}-\mathrm{Pb}-\mathrm{W}$ skarn.

Commodities of interest: Mo, W, Cu.

Name(s) of mines and(or) prospects (Locality numbers from Grybeck and others, 1984): Dry Pass (50) and Devilfish Bay (54) occurrences.

Production: None reported.

Quantified resources: None reported.

Level of past exploration activity: Low.

\section{Geophysics}

Aeromagnetic features: Large high anomaly associated with northern Prince of Wales Island plutons.

Gravity features: Large low associated with above plutons.

Aeroradioactivity features: Large high associated with above plutons.

Telegeologic features: Large linear arcuate feature immediately west of tract.

Exploration geochemistry

Stream-sediment and(or) panned-concentrate geochemical anomalies: Small scattered W, Mo; same as tracts 5 and 8.

Bedrock geochemical anomalies: Small scattered $\mathrm{Mo}, \mathrm{Cu}, \mathrm{Bi}$; same as tracts 5 and 8 .

Resource assessment

Classification of resources (see Appendix A): Undiscovered speculative $\mathrm{Mo}, \mathrm{Cu}, \mathrm{W}$ resources; subeconomic; unqualified; low probability of occurrence.

Discussion: Overlaps tracts 5 and 8 in part.

References: Herreid and Kaufman, 1964; Grybeck and others, 1984. 
MINERAL-RESOURCE TRACT NO. 17

Rank: III

Tract name and location: Le Conte Bay-Stikine River; mainland east and northeast of Petersburg.

Tract boundaries based on distribution of: Stream-sediment and bedrock geochemical anomalies and pelitic schists.

\section{Mineral deposits}

Type(s) of deposits known or inferred to be present: Au-quartz vein, metamorphosed massive sulfide(?).

Commodities of interest: $\mathrm{Au}, \mathrm{Pb}, \mathrm{Zn}$.

Name(s) of mines and(or) prospects (Locality numbers from Grybeck and others, 1984): Le Conte Bay (21) occurrence.

Production: None reported.

Quantified resources: None reported.

Level of past exploration activity: Low.

\section{Geophysics}

Aeromagnetic features: Adjacent to strong major regional gradient; some isolated strong, small anomalies to wert.

Gravity features: On steep gradient.

Aeroradioactivity features: None known.

Telegeologic features: Dense linears of Coast Range megalineament in tract.

Exploration geochemistry

Stream-sediment and(or) panned-concentrate geochemical anomalies: $\mathrm{Zn}, \mathrm{Au}, \mathrm{As}$.

Bedrock geochemical anomalies: $\mathrm{Pb}, \mathrm{Zn}, \mathrm{Au}, \mathrm{Mo}$.

Besource assessment

Classification of resources (see Appendix A): Undiscovered speculative $\mathrm{Au}, \mathrm{Pb}, \mathrm{Zn}$ resources; subeconomic: unquantified; low probability of occurrence.

Discussion: Overlaps with tract 3 to south.

References: Buddington, 1923; Grybeck and others, 1984. 
Rank: III

Tract name and location: Thorne and Stevenson Islands; northeastern Prince of Wales Island.

Tract boundaries based on distribution of: Stream-sediment and bedrock geochemical anomalies.

\section{Mineral deposits}

Type(s) of deposits known or inferred to be present: Sedimentary exhalative $\mathrm{Zn}$ - $\mathrm{Pb}$.

Commodities of interest: $\mathrm{Cu}, \mathrm{Pb}, \mathrm{Zn}, \mathrm{Mo}$.

Name(s) of mines and(or) prospects (Locality numbers from Grybeck and others, 1984): None resent.

Production: None reported.

Quantified resources: None reported.

Level of past exploration activity: None.

\section{Geophysics}

Aeromagnetic features: Between two linear highs of moderate strength and size.

Gravity features: At northern end of broad high.

Aeroradioactivity features: None observed.

Telegeologic features: None observed.

Exploration geochemistry

Stream-sediment and(or) panned-concentrate geochemical anomalies: Two overlapping areas, one with Mo, $\mathrm{Cu}, \mathrm{Zn}$, and the other with $\mathrm{Cu}, \mathrm{Pb}, \mathrm{Zn}$.

Bedrock geochemical anomalies: $\mathrm{Cu}, \mathrm{Pb}, \mathrm{Zn}$, minor $\mathrm{Cr}$ and $\mathrm{Ni}$.

Resource assessment

Classification of resources (see Appendix A): Undiscovered speculative $\mathrm{Cu}, \mathrm{Pb}, \mathrm{Zn}$ resources; subeconomir; unquantified; high probability of occurrence.

Discussion: No evidence of mineralization found.

References: None. 
MINERAL-RESOURCE TRACT NO. 19

Rank: III

Tract name and location: Zarembo and Etolin Islands.

Tract boundaries based on distribution of: Middle Tertiary granitic rocks and bedrock geochemical anomalie-

Mineral deposits

Type(s) of deposits known or inferred to be present: Polymetallic vein, porphyry Mo.

Commodities of interest: $\mathrm{Mo}, \mathrm{W}, \mathrm{Cu}, \mathrm{Pb}, \mathrm{Zn}, \mathrm{Au}, \mathrm{Ag}, \mathrm{Cr}, \mathrm{Ni}$.

Name(s) of mines and(or) prospects (Locality numbers from Grybeck and others, 1984): None.

Production: None reported.

Quantified resources: None reported.

Level of past exploration activity: Moderate.

\section{Geophysics}

Aeromagnetic features: Pluton-associated moderate to strong, large- to moderate-sized anomalies in most of tract.

Gravity features: Alternating highs and low, mostly lows.

Aeroradioactivity features: Local moderate anomalies; see tract 30.

Telegeologic features: Several arcuate linears in tract.

Exploration geochemistry

Stream-sediment and(or) panned-concentrate geochemical anomalies: $\mathrm{Mo}, \mathrm{W}$ over most of tract; $\mathrm{Ni}, \mathrm{Cr}, \mathrm{Pb}$ in southeast part; $\mathrm{Pb}, \mathrm{Nb}$ in northwest part.

Bedrock geochemical anomalies: $\mathrm{Cu}, \mathrm{Pb}, \mathrm{Zn}, \mathrm{Au}, \mathrm{Mo}, \mathrm{Cr}, \mathrm{Ni}$.

Resource assessment

Classification of resources (see Appendix A): Undiscovered speculative $\mathrm{Cu}, \mathrm{Pb}, \mathrm{Zn}$, Mo resources; subeconcmic; unquantified; high probability of occurrence.

Discussion: Overlaps tracts 1 and 30 in part.

References: None. 
MINERAL-RESOURCE TRACT NO. 20

Rank: III

Tract name and location: Saginaw Bay; northern Kuiu Island.

Tract boundaries based on distribution of: Stream-sediment and bedrock geochemical anomalies.

Mineral deposits

Type(s) of deposits known or inferred to be present: Polymetallic vein(s).

Commodities of interest: $\mathrm{Cu}, \mathrm{Pb}, \mathrm{Zn}, \mathrm{Mo}, \mathrm{Cr}, \mathrm{Ni}, \mathrm{Co}$.

Name(s) of mines and(or) prospects (Locality numbers from Grybeck and others, 1984): Saginaw Bay (1) occurrence (see tract 13).

Production: None reported.

Quantified resources: None reported.

Level of past expioration activity: Low.

\section{Geophysics}

Aeromagnetic features: In low between two strong highs.

Gravity features: Mostly in low.

Aeroradioactivity features: None observed.

Telegeologic features: Linears parallel to bay and fault zone.

Expleration geochemistry

Stream-sediment and(or) panned-concentrate geochemical anomalies: $\mathrm{Mo}, \mathrm{Ba}$.

Bedrock geochemicai anomalies: $\mathrm{Cu}, \mathrm{Pb}, \mathrm{Zn}, \mathrm{Mo}, \mathrm{Ni}, \mathrm{Cr}$, $\mathrm{Co}$.

Resource assessment

Classification of resources (see Appendix A): Undiscovered speculative $\mathrm{Cu}, \mathrm{Pb}, \mathrm{Zn}$, Mo resources; subeconomic; unquantified; low probability of occurrence.

Discussion: Overlaps tract 13 in part; deposit type not established.

References: None. 
Rank: III

Tract name and location: Northeast of Kake; northwestern Kupreanof Island.

Tract boundaries based on distribution of: Bedrock geochemical anomalies.

Mineral deposits

Type(s) of deposits known or inferred to be present: Sedimentary exhalative $\mathrm{Zn}-\mathrm{Pb}(?)$.

Commodities of interest: $\mathrm{Cu}, \mathrm{Zn}$.

Name(s) of mines and(or) prospects (Locality numbers from Grybeck and others, 1984): None.

Production: None reported.

Quantified resources: None reported.

Level of past exploration activity: None(?).

\section{Geophysics}

Aeromagnetic features: Linear anomaly through tract.

Gravity features: None observed.

Aeroradioactivity features: None observed.

Telegeologic features: Two arcuate linears near tract.

Exploration geochemistry

Stream-sediment and(or) panned-concentrate geochemical anomalies: None detected.

Bedrock geochemical anomalies: $\mathrm{Cu}, \mathrm{Zn}$.

Resource assessment

Classification of resources (see Appendix A): Undiscovered speculative $\mathrm{Cu}, \mathrm{Zn}$ resources; subeconomic; unquantified; low probability of occurrence.

Discussion: Adjoins tract 22; deposit type not established.

References: None. 
Rank: $\quad$ itt

Tract name and location: Northeast of Kake; northwestern Kupreanof Island.

Tract boundaries based on distribution of: Bedrock and stream-sediment geochemical anomalies.

Mineral deposits

Type(s) of deposits known or inferred to be present: Besshi massive sulfide(?).

Commodities of interest: $\mathrm{Cu}, \mathrm{Pb}, \mathrm{Ni}, \mathrm{Cr}, \mathrm{Mo}$.

Name(s) of mines and(or) prospects (Locality numbers from Grybeck and others, 1984): None.

Production: None reported.

Quantified resources: None reported.

Level of past exploration activity: None(?).

\section{Geophysics}

Aeromagnetic features: Linear anomaly through tract.

Gravity features: None observed.

Aeroradioactivity features: None observed.

Telegeologic features: Two arcuate linears near tract.

Exploration geochemistry

Stream-sediment and(or) panned-concentrate geochemical anomalies: $\mathrm{Ni}$, Co.

Bedrock geochemical anomalies: $\mathrm{Cu}, \mathrm{Pb}, \mathrm{Ni}, \mathrm{Cr}, \mathrm{Mo}$.

Resource assessment

Classification of resources (see Appendix A): Undiscovered speculative $\mathrm{Cu}, \mathrm{Pb}, \mathrm{Ni}, \mathrm{Cr}, \mathrm{Mo}$ resources; subeconomic; unquantified; high probability of occurrence.

Discussion: Adjoins tract 21; deposit type not established.

References: None. 
MINERAL-RESOURCE TRACT NंO. 23

Rank:

III

Tract name and location: Turn Mountain; northwestern Kupreanof Island.

Tract boundaries based on distribution of: Bedrock and stream-sediment geochemical anomalies.

Mineral deposits

Type(s) of deposits known or inferred to be present: Gabbroic Ni-Cu, zoned mafic-ultramafic $\mathrm{Cr}$-Cu-Ni.

Commodities of interest:

Name(s) of mines and(or) prospects (Locality numbers from Grybeck and others, 1984): None.

Production: None reported.

Quantified resources: None reported.

Level of past exploration activity: None(?).

\section{Geophysics}

Aeromagnetic features: Very strong, moderate-sized high.

Gravity features: Strong, large high.

Aeroradioactivity features: None observed.

Telegeologic features: Arcuate linears present.

Exploration geochemistry

Stream-sediment and(or) panned-concentrate geochemical anomalies: $\mathrm{Cu}, \mathrm{Zn}$.

Bedrock geochemical anomalies: $\mathrm{Co}, \mathrm{Cr}, \mathrm{Cu}, \mathrm{Pb}, \mathrm{Zn}, \mathrm{Mo}$.

Besource assessment

Classification of resources (see Appendix A): Undiscovered speculative $\mathrm{Co}, \mathrm{Cr}, \mathrm{Ni}$ resources; subeconomic: unquantified; high probability of occurrence.

Discussion: Co anomalies in different rock types; $\mathrm{Cr}$ anomaly is not above that expected from ultramafic rocks.

References: None. 
Rank:

III

Tract name and location: Sukoi and Mitkof Islands; near Petersburg.

Tract boundaries based on distribution of: Aeromagnetic anomalies.

Mineral deposits

Type(s) of deposits known or inferred to be present: Zoned mafic-ultramafic $\mathrm{Cr}-\mathrm{Cu}-\mathrm{Ni}$, gabbroic $\mathrm{Ni}-\mathrm{Cu}$.

Commodities of interest:

Name(s) of mines and(or) prospects (Locality numbefs frón Grybeck and others, 1984): None.

Production: None reported.

Quantified resources: None reported.

Level of past exploration activity: Low(?).

Geophysics

Aeromagnetic features: Moderate to strong, small- to moderate-sized anomalies.

Gravity features: None reported.

Aeroradioactivity features: None observed.

Telegeologic features: None observed.

\section{Expleration geochemistry}

Stream-sediment and(or) panned-concentrate geochemical anomalies: None.

Bedrock geochemical anomalies: $\mathrm{Co}, \mathrm{Cr}, \mathrm{Ni}, \mathrm{Cu}$.

Resource assessment

Classification of resources (see Appendix A): Undiscovered speculative $\mathrm{Co}, \mathrm{Cr}, \mathrm{Ni}, \mathrm{Cu}$ resources; subeconcmic; unquantified; moderate probability of occurrence.

Discussion: None.

References: None. 
MINERAL-RESOURCE TRACT NO. 25

Rank: $\quad$ III

Tract name and location: Coffman Cove; northeastern Prince of Wales Island.

Tract boundaries based on distribution of: Stream-sediment and bedrock geochemical anomalies.

Mineral deposits

Type(s) of deposits known or inferred to be present: Polymetallic vein(?).

Commodities of interest: $\mathrm{Cr}, \mathrm{Ni}, \mathrm{Cu}$.

Name(s) of mines and(or) prospects (Locality numbers from Grybeck and others, 1984): None.

Production: None reported.

Quantified resources: None reported.

Levei of past exploration activity: None(?).

\section{Geophysics}

Aeromagnetic features: Small linear anomaly; next to interpreted fault.

Gravity features: Small positive anomaly.

Aeroradioactivity features: None observed.

Telegeologic features: None observed.

Exploration geochemistry

Stream-sediment and(or) panned-concentrate geochemical anomalies: $\mathrm{Cr}, \mathrm{Ni}, \mathrm{Cu}$.

Bedrock geochemical anomalies: $\mathrm{Cu}, \mathrm{Pb}, \mathrm{Zn}, \mathrm{Co}, \mathrm{Cr}, \mathrm{Ni}$.

Resource assessment

Classification of resources (see Appendix A): Undiscovered speculative $\mathrm{Cu}, \mathrm{Pb}, \mathrm{Zn}, \mathrm{Co}, \mathrm{Cr}, \mathrm{Ni}$ resources; subeconomic; unquantified; high probability of occurrence.

Discussion: This area might be on the southern extension of tract 11 .

References: None. 
MINERAL-RESOURCE TRACT NO. 26

Rank: $\quad$ III

Tract name and location: Canoe Passage; Etolin Island

Tract boundaries based on distribution of: Bedrock geochemical samples along Canoe Passage fault zone.

Mineral deposits

Type(s) of deposits known or inferred to be present: Polymetallic vein.

Commodities of interest: $\mathrm{Cu}, \mathrm{Mo}$.

Name(s) of mines and(or) prospects (Locality numbers from Grybeck and others, 1984): None.

Production: None reported.

Quantified resources: None reported.

Level of past exploration activity: None to low.

\section{Geophrsics}

Aeromagnetic features: None observed.

Gravity features: None observed.

Aeroradioactivity features: None detected.

Telegeologic features: Strong linear along Canoe Passage fault zone.

Exploration geochemistry

Stream-sediment and(or) panned-concentrate geochemical anomalies: None detected.

Bedrock geochemical anomalies: $\mathrm{Cu}, \mathrm{Mo}, \mathrm{Ni}$.

Resource assessment

Classification of resources (see Appendix A): Undiscovered speculative $\mathrm{Cu}$, Mo resources; subeconomic; unquantified; low probability of occurrence.

Discussion: Overlaps part of tract 19.

References: None. 
Rank: $\quad$ III

Tract name and bocation: · Kupreanof, Zarembo, and Etolin Islands.

Tract boundaries based on distribution of: Middle Tertiary alkalic and subalkalic plutons.

Mmeral. deposits

Type(s) of 'deposits known or inferred 'to be present: Felsic plutonic U.

Commoditles of interest: REE, $U$, Th.

Name(s) of mines and(br) prospects: (Locality. numbers. from . Grybeck and others, 1984): None.

Production: None reported.

Quantified resources: Nơne reported.

Level of past exploration' 'activity': Low to moderate.

\section{Geophysics}

Aeromagnetic feàtures: 'Sevieral 'mờderàte: tol strong,; moderate-- to large-sized anomalies (see tract 19).

Gravitỳ features: Nöne reportèd:

Aeroradioactivify' 'feátures: : Loçal móderate anomalies (see tract 19).

Télêgeologic' 'feàturešs!' Arcuate 'linears in several areas.

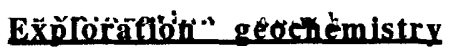

Stream-sédímëñ̀t 'and(br') panthedsconcentrate geochemical anomalles: $\mathrm{La}, \mathrm{Nb}, \mathrm{Y}, \mathrm{Pb}$.

Bedrock' geoochenemileàl' anomálies: $\mathrm{Be}, \mathrm{Nb}, \mathrm{Sn}, \mathrm{Cu}, \mathrm{Mo}, \mathrm{La}, \mathrm{Co}, \mathrm{Cr}$.

Rèsouircè assessment

Classifiçatiòn of rèsoutces (see 'Appendix A): Undiscovered speculative $\mathrm{Be}, \mathrm{Nb}, \mathrm{La}, \mathrm{Y}$ resources; subecononic; unquantified; moderate probability of occurrence.

Discussion: Overlaps parts of tracts $1,14,19$, and 30.

References: None. 
MINERAL-RESOURCE TRACT NO. 28

Rank: $\quad$ IV

Tract name and location: Kuiu, Kupreanof, and Zarembo Islands.

Tract boundaries based on distribution of: Lower Tertiary Kootznahoo Formation.

Mineral deposits

Type(s) of deposits known or inferred to be present: Sandstone U.

Commodities of interest: $\mathrm{U}$, Th.

Name(s) of mines and(or) prospects (Locality numbers from Grybeck and others, 1984): Port Camden $(7,8)$ and Hamilton Creek $(10)$ occurrences.

Production: None reported.

Quantified resources: None reported.

Level of past exploration activity: Moderate to high.

\section{Geophysics}

Aeromagnetic features: None observed

Gravity features: None observed.

Aeroradioactivity features: Local small anomalies.

Telegeologic features: None observed.

Expleration geochemistry

Stream-sediment and(or) panned-concentrate geochemical anomalies: None.

Bedrock geochemical anomalies: U.

Resource assessment

Classification of resources (see Appendix A): Undiscovered $U$ and Th resources; subeconomic; unquantified; moderate probability of occurrence.

Discussion: Masked largely by middle Tertiary volcanic rocks (see tract 14); overlapped by several other tracts; all known outcrop areas were overflown by low-flight-level, helicopter-mounted, 4-channel radiometor survey.

References: Eakins, 1975; Dickinson, 1979a,b; Dickinson and Campbell, 1983; Dickinson and Pierson, 1988;

Dickinson and Vuletich, in press. 
Rank: $\quad$ IV

Tract name and location: Portage Mountain; northem Kupreanof Island.

Tract boundaries based on distribution of: Aeromagnetic anomaly.

Mineral deposits

Type(s) of deposits known or inferred to be present: None known.

Commodities of interest: $\mathrm{Cu}(?)$.

Name(s) of mines and(or) prospects (Locality numbers from Grybeck and others, 1984): None.

Production: None reported.

Quantified resources: None reported.

Level of past exploration activity: None(?).

\section{Geophysics}

Aeromagnetic features: Strong, large high.

Gravity features: None observed.

Aeroradioactivity features: None observed.

Telegeologic features: None observed.

Exploration geochemistry

Stream-sediment and(or) panned-concentrate geochemical anomalies: None detected.

Bedrock geochemical anomalies: $\mathrm{Cu}$.

Resource assessment

Classification of resources (see Appendix A): Not applicable.

Discussion: Overlaps part of tract 1.

References: None. 
Rank:

$\mathrm{V}$

Tract name and location: Steamer Knoll; northwestern Etolin Island.

Tract boundaries based on distribution of: Aeromagnetic anomaly.

Mineral deposits

Type(s) of deposits known or inferred to be present: None known.

Commodities of interest: None known.

Name(s) of mines and(or) prospects (Locality numbers from Grybeck and others, 1984): None.

Production: None reported.

Quantified resources: None reported.

Level of past exploration activity: Moderate.

\section{Geophysics}

Aeromagnetic features: Strong, large anomaly.

Gravity features: None observed.

Aeroradioactivity features: None detected.

Telegeologic features: Strong linears.

Exploration geochemistry

Stream-sediment and(or) panned-concentrate geochemical anomalies: None.

Bedrock geochemical anomalies: None.

Resource assessment

Classification of resources (see Appendix A): Not applicable.

Discussion: Source of aeromagnetic anomaly is unclear.

References: None. 
Rank:

V

Tract name and location: Zarembo Island and Zimovia Straits.

Tract boundaries based on distribution of: Aeromagnetic anomalies.

Mineral deposits

Type(s) of deposits known or inferred to be present: None known.

Commodities of interest: $\mathrm{Co}, \mathrm{Cr}, \mathrm{Ni}, \mathrm{Cu}$.

Name(s) of mines and(or) prospects (Locality numbers from Grybeck and others, 1984): None.

Production: None reported.

Quantified resources: $\cdot$ None reported.

Level of past exploration activity: None.

\section{Geophrsics}

Aeromagnetic features: Strong, small highs associated with hornblendite bodies.

Gravity features: None observed.

Aeroradioactivity features: None observed.

Telegeologic features: None observed.

Exploration geochemistry

Stream-sediment and(or) panned-concentrate geochemical anomalies: None.

Bedrock geochemical anomalies: $\mathrm{Co}, \mathrm{Cr}, \mathrm{Ni}$.

Resource assessment

Classification of resources (see Appendix A): Not applicable.

Discussion: None.

References: None. 


\section{REFERENCES CITED}

Barnes, D.F., 1972a, Summary operational report of a preliminary gravity survey of southeastern Alaska: U.S. Geological Survey open-file report (informal no. 524), 16 sheets.

-1972b, Sixteen 1:250,000 simple Bouguer gravity anomaly maps of southeastern Alaska showing station locations, anomaly values, and generalized 10-milligal contours: U.S. Geological Survey open-file report (informal no. 525), 16 sheets.

1972c, Southeast Alaska gravity base station network: U.S. Geological Survey open-file report (informal no. 526), 40 p.

Barnes, D.F., Brew, D.A., and Morin, R.L., 1989, Bouguer gravity map of the Petersburg quadrangle and parts of the Port Alexander, Sitka, and Sumdum quadrangles, Alaska: U.S. Geological Survey Miscellaneous Field Studies Map MF-1970-A, scale $1: 250,000$.

Barnes, D.F., Erwin, M.J., Holden, K.D., and Morin, R.L., 1975, USGS gravity data maps of the Port Alexander, Sitka, Juneau, Mt. Fairweather, and Skagway 1:250,000 quadrangles, Alaska: U.S. Geological Survey Open-File Report 75-6, 5 maps, $58 \mathrm{p}$.

Barnes, D.F., Olson, R.C., Holden, K.D., Morin, R.L., and Erwin, M.J., 1972a, Tabulated gravity data from southeastem Alaska obtained during the 1968 field season: U.S. Geological Survey open-file report (informal no. 527), $76 \mathrm{p}$.

Barnes, D.F., Popenoe, Peter, Olson, R.C., MacKenzie, M.V., and Morin, R.L., 1972b, Tabulated gravity data from southeastern Alaska obtained during the 1969 field season: U.S. Geological Survey openfile report (informal no. 528 ), 75 p.

Berg, H.C., 1981, Upper Triassic volcanogenic massive sulfide metallogenic province identified in southeastern Alaska, in Albert, N.R.D., and Hudson, Travis, eds., United States Geological Survey in Alaska: Accomplishments during 1979: U.S. Geological Survey Circular 823-B, p. B104B108.

Berg, H.C., and Cobb, E.H., 1967, Metalliferous lode deposits of Alaska: U.S. Geological Survey Bulletin 1246, 254 p.

Berg, H.C., and Grybeck, Donald, 1980, Upper Triassic volcanogenic $\mathrm{Zn}-\mathrm{Pb}-\mathrm{Ag}(-\mathrm{Cu}-\mathrm{Au})$-barite mineral deposits near Petersburg, Alaska: U.S. Geological Survey Open-File Report 80-527, 11 p.

Brew, D.A., and Ford, A.B., 1978, Megalineament in southeastern Alaska marks the southwest edge of Coast Range batholithic complex: Canadian Journal of Earth Science, v. 15, no. 11, p. 1763 1772.

Brew, D.A., Grybeck, D.J., Cathrall, J.B., Karl, S.M., Koch, R.D., Barnes, D.F., Griscom, A., and Berg, H.C., 1987, Mineral-resource assessment process and results, Petersburg project area, southeastern Alaska [abs.] in Sachs, J.S., ed., United States Geological Survey research on mineral resources--
1987: U.S. Geological Survey Circular 995, p. 89.

Brew, D.A., Ovenshine, A.T., Karl, S.M., and Hunt, S.J., 1984, Preliminary reconnaissance geologic map of the Petersburg and parts of the Port Alexander and Sumdum 1:250,000 quadrangles, southeastern Alaska: U.S. Geological Survey Open-File Reprrt 84-405, 2 sheets, 43 p.

Buddington, A.F., 1923, Mineral deposits of the Wrangell district: U.S. Geological Survey Bulletin 739 , p. $51-75$.

1925, Mineral investigations in southeastern Alaska: U.S. Geological Survey Bulletin 733, p. 71-139.

1930, Molybdenite deposit at Shakan, Alaska: Economic Geology, v. 25, p. 197-200.

Buddington, A.F., and Chapin, Theodore, 1929, Geolc $¥ \mathbf{y}$ and mineral deposits of southeastern Alaska: U.S. Geological Survey Bulletin 800, 398 p.

Burchard, E.F., 1914, A barite deposit near Wrangell: U.S. Geological Survey Bulletin 592, p. 109-117.

Burrell, P.D., Cobb, E.H., and Brew, D.A., 1982 , Geologic bibliography of the Petersburg projict area, Alaska: U.S. Geological Survey Open-File Report 82-483, 30 p.

Cathrall, J.B., Day, G.W., Hoffman, J.D., and McDaral, S.K., 1983a, A listing and statistical summary of analytical results for pebbles, stream sedimerts, and heavy-mineral concentrates from stream sediments, Petersburg area, southeast Alaska: U.S. Geological Survey Open-File Report 83-420-A, 281 p., scale 1:250,000, 1 sheet.

1983b, Distribution and abundance of copp $:$, determined by stream sediments, Petersburg ar $: a$, southeast Alaska: U.S. Geological Survey OpenFile Report 83-420-B, scale 1:250,000, 1 sheet.

-1983c, Distribution and abundance of coppar, determined by spectrographic analysis, in nonmagnetic fraction of heavy-mineral concentrates from stream sediments, Petersburg area, southeast Alaska: U.S. Geological Survey Open-File Report 83-420-C, scale 1:250,000, 1 sheet.

1983d, Distribution and abundance of lead, determined by spectrographic analysis, in nonmagnetic fraction of heavy-mineral concentrates from stream sediments, Petersbirg area, southeast Alaska: U.S. Geological Survey Open-File Report 83-420-D, scale 1:250,000, 1 sheet.

1983e, Distribution and abundance of lead, determined by spectrographic analysis, in nonmagnetic fraction of heavy-mineral concentrates from stream sediments, Petersbrrg area, southeast Alaska: U.S. Geological Survey Open-File Report 83-420-E, scale 1:250,000, 1 sheet.

1983f, Distribution and abundance of zinc, determined by spectrographic analysis, in the minus-80-mesh fraction of stream sedimerts, Petersburg area, southeast Alaska: U.S. Geologi`al 
Survey Open-File Report 83-420-F, scale $1: 250,000,1$ sheet.

$1983 \mathrm{~g}$, Distribution and abundance of zinc, determined by spectrographic analysis, in nonmagnetic fraction of heavy-mineral concentrates from stream sediments, Petersburg area, southeast Alaska: U.S. Geological Survey Open-File Report 83-420-G, scale 1:250,000, 1 sheet.

-1983h, Distribution and abundance of barium, determined by spectrographic analysis, in the minus-80-mesh fraction of stream sediments, Petersburg area, southeast Alaska: U.S. Geological Survey Open-File Report 83-420-H, scale 1:250,000, 1 sheet.

-1983i, Distribution and abundance of barium, determined by spectrographic analysis, in nonmagnetic fraction of heavy-mineral concentrates from stream sediments, Petersburg area, southeast Alaska: U.S. Geological Survey Open-File Report 83-420-I, scale 1:250,000, 1 sheet.

-1983j, Distribution and abundance of determinable silver by spectrographic analysis, in nonmagnetic fraction of heavy-mineral concentrates from stream sediments, Petersburg area, southeast Alaska: U.S. Geological Survey Open-File Report 83-420-J, scale 1:250,000, 1 sheet.

-1983k, Distribution and abundance of detectable gold, arsenic, bismuth, and antimony in the nonmagnetic fraction of heavy-mineral concentrates and in the minus-80-mesh fraction from stream sediments, Petersburg area, southeast Alaska: U.S. Geological Survey Open-File Report $83-420-\mathrm{K}$, scale $1: 250,000,1$ sheet.

19831, Distribution and abundance of tin determined by heavy-mineral concentrates from stream sediments, Petersburg area, southeast Alaska: U.S. Geological Survey Open-File Report 83-420-L, scale 1:250,000, 1 sheet.

-1983m, Distribution and abundance of cadmium determined by spectrographic analysis in nonmagnetic fraction of heavy-mineral concentrates from stream sediments, Petersburg area, southeast Alaska: U.S. Geological Survey Open-File Report $83-420-\mathrm{M}$, scale 1:250,000, 1 sheet.

-1983n, Distribution and abundance of molybdenum, determined by spectrographic analysis, in the minus-80-mesh fraction of stream sediments, Petersburg area, southeast Alaska: U.S. Geological Survey Open-File Report 83-420-N, scale $1: 250,000,1$ sheet.

1983o, Distribution and abundance of molybdenum, determined by spectrographic analysis, in nonmagnetic fraction of heavymineral concentrates from stream sediments, Petersburg area, southeast Alaska: U.S. Geological Survey Open-File Report 83-420-O, scale $1: 250,000,1$ sheet. 1983p, Distribution and abundance of nickel, determined by spectrographic analysis, in the minus-80-mesh fraction of stream sediments, Petersburg area, southeast Alaska: U.S. Geological Survey Open-File Report 83-420-P, s?ale $1: 250,000,1$ sheet.

-1983q, Distribution and abundance of nickel, determined by spectrographic analysis, in nonmagnetic fraction of heavy-minaral concentrates from stream sediments, Petershurg area, southeast Alaska: U.S. Geological. Su'vey Open-File Report 83-420-Q, scale 1:250,00?, 1 sheet.

-1983r, Distribution and abundance of cohalt, determined by spectrographic analysis, in the minus-80-mesh fraction of stream sediments, Petersburg area, southeast Alaska: U.S. Geolo?ical Survey Open-File Report 83-420-R, s sale $1: 250,000$, 1 sheet.

-1983s, Distribution and abundance of cohalt, determined by spectrographic analysis, in the nonmagnetic fraction of heavy-mineral concentrates from stream sediments, Petershurg area, southeast Alaska: U.S. Geological Survey Open-File Report 83-420-S, scale 1:250,00?, 1 sheet.

1983t, Distribution and abundance of chromium, as determined by spectrographic analysis, in the minus-80-mesh fraction of stream sediments, Petersburg area, southeast Alaska: U.S. Geolorical Survey Open-File Report 83-420-T, scale $1: 250,000,1$ sheet.

1983u, Distribution and abundance of chromium, determined by spectrographic analysis, in the nonmagnetic fraction of heavy-mineral concentrates from stream sediments, Petershurg area, southeast Alaska: U.S. Geological Survey Open-File Report 83-420-U, scale 1:250,007, 1 sheet.

$-1983 \mathrm{v}$, Distribution and abundance of tungrten, determined for colorimetric and spectrographic analysis, in the minus-80-mesh fraction of st-oam sediment, Petersburg area, southeast Alaska: U.S. Geological Survey Open-File Report 83-427-V, scale $1: 250,000,1$ sheet.

-1983w, Distribution and abundance of tung ${ }^{-t e n}$, determined by spectrographic analysis, in nonmagnetic fraction of heavy-mireral concentrates from stream sediments, Petershurg area, southeast Alaska: U.S. Geological Survey Open-File Report 83-420-W, scale 1:250,0C?, 1 sheet.

Chapin, Theodore, 1918, Mining developments ir the Ketchikan and Wrangell mining districts: U.S. Geological Survey Bulletin 662, p. 63-75.

Clark, A.L., and Greenwood, W.R., 1972, Geochem istry and distribution of platinum-group metals in mafic to ultramafic complexes of southern and southeastern Alaska, in Geological Survey research: U.S. Geological Survey Professional Paper 800-C, p. C157-C160. 
Cobb, E.H., 1978, Summary of references to mineral occurrences (other than mineral fuels and construction materials) in the Port Alexander quadrangle, Alaska: U.S. Geological Survey OpenFile Report 78-870, $52 \mathrm{p}$.

Cox, Dennis, 1983a, U.S. Geological SurveyINGEOMINAS Mineral Resource Assessment of Columbia: Ore deposit models: U.S. Geological Survey Open-File Report 83-423, 64 p. 1983b, U.S. Geological Survey-INGEOMINAS Mineral Resource Assessment of Columbia: Additional ore deposit models: U.S. Geological Survey Open-File Report 83-901, 32 p.

Cox, D.P., and Singer, D.A., eds., 1986, Mineral deposit models: U.S. Geological Survey Bulletin 1693, $379 \mathrm{p}$.

Dickinson, K.A., 1979a, Uraniferous phosphate occurrence on Kupreanof Island, southeast Alaska: U.S. Geological Survey Open-File Report 79-1316, $2 \mathrm{p}$.

1979b, A uranium occurrence in the Tertiary Kootznahoo Formation on Kuiu Island, southeast Alaska: U.S. Geological Survey Open-File Report 79-1427, 5 p.

Dickinson, K.A., and Campbell, J.A., 1983, The potential for uranium deposits in the Tertiary Kootznahoo Formation of the southern part of the Admiralty trough, southeastern Alaska: U.S. Geological Survey Open-File Report 82-983.

1984, Uranium geology of the Tertiary Kootznahoo Formation of the southern part of the Admiralty trough, southeastern Alaska: Joumal of the Alaska Geological Society, v. 4, p. 1-11.

Dickinson, K.A., and Pierson, C.T., 1988, A statistical analysis of chemical and mineralogic data from the Tertiary Kootznahoo Formation in southeastern Alaska, with emphasis on uranium and thorium: U.S. Geological Survey Bulletin 1851, 19 p.

Dickinson, K.A., and Vuletich, April, in press, Diagenesis and uranium mineralization of the lower Tertiary Kootznahoo Formation in the northern part of Admiralty trough, southeastern Alaska: U.S. Geological Survey Bulletin 1888.

Eakins, G.R., 1975, Uranium investigations in southeastern Alaska: Alaska Division of Geological and Geophysical Surveys Geologic Report 44, 62 p.

Erickson, R.L., 1982, Characteristics of mineral deposit occurrences: U.S. Geological Survey Open-File Report 82-795, 248 p.

Gault, H.R., Rossman, D.L., Flint, G.M., Jr., and Ray, R.G., 1953, Some lead-zinc deposits of the Wrangell district, Alaska: U.S. Geological Survey Bulletin 998-B, p. 15-58.

Grybeck, D.J., Berg, H.C., and Karl, .S.M., 1984, Map and description of the mineral deposits in the Petersburg and eastern Port Alexander quadrangles, southeastern Alaska: U.S. Geological Survey Open-File Report 84-837, 1 sheet, 87 p.

Herreid, Gordon, and Kaufman, M.A., 1964, Geology of the Dry Pass area, southeastern Alaska: Alaska
Division of Mines and Minerals Geologic Feport 7, 12 p.

Himmelberg, G.R., Loney, R.A., and Craig, J.T., 1986, Petrogenesis of the ultramafic complex at the Blashke Islands, southeastern Alaska: U.S. Geological Survey Bulletin 1662, 14 p.

Houston, J.R., Bates, R.G., Velikanje, R.S., and Wedow, Helmuth, Jr., 1958, Reconnaissance for radio 7 ctive deposits in southeastern Alaska, 1952: U.S. Geological Survey Bulletin 1058-A, p. 1-31.

Hudson, T., Plafker, G., and Dixon, K., 1982, Horizontal offset history of the Chatham Strait fault, in Coonrad, W.L., ed., The United States Geological Survey in Alaska: Accomplishments during 1980: U.S. Geological Survey Circular 844, p. 128-132.

Hunt, S.J., 1984, Preliminary study of a zoned leucocratic-granite body on Central Etolin Island, southeastern Alaska, in Coonrad, W.L., and F'liott, R.L., eds., The United States Geological Survoy in Alaska: Accomplishments during 1981: U.S. Geological Survey Circular 868, p. 128-131.

Karl, S.M., Berg, H.C., Grybeck, D.J., and Abramson, B.S., 1980, Tables describing metalliferou: and selected nonmetallic mineral deposits in the Petersburg and eastern Port Alexander quadrangles, Alaska: U.S. Geological Survey Open-File Keport 80-793, 14 p., 4 sheets, scale 1:250,000.

Karl, S.M., Koch, R.D., Hoffman, J.D., Day, G.W., Sutley, S.J., and McDanal, S.K., 1985, Traceelement data for rock samples from the Peters burg, and parts of the Port Alexander and Sumdum quadrangles, southeastern Alaska: U.S. Geological Survey Open-File Report 85-146, 1 sheet, $69 \AA$ p.

Kennedy, G.C., and Walton, M.S., Jr., 1946, Ge $>$ logy and associated mineral deposits of some ultrabasic rock bodies in southeastern Alaska: U.S. Geological Survey Bulletin 947-D, p. 65-84.

Kerns, W.H., 1950, Investigations of Taylor Creek leadzinc deposit, Kupreanof Island, Petersburg, Alaska: U.S. Bureau of Mines Report of Investigations 4669, 13 p.

Le Compte, J.R., 1981, Landsat features maps of the Petersburg quadrangle and vicinity, southeastern Alaska: U.S. Geological Survey Open-File F.eport 81-799, 2 sheets, scale $1: 250,000$.

Newberry, R.J., and Brew, D.A., 1989, Epigenetic hydrothermal origin for the Groundhog FasinGlacier Basin silver-tin-lead-zinc deposits, southeastern Alaska, in Dover, J.H., and Gall wway, J.P., eds., Geologic studies in Alaska by the. U.S. Geological Survey, 1988: U.S. Geological Survey Bulletin 1903, p. 113-121.

Nokleberg, W.J., Bundtzen, T.K., Berg, H.C., Brew, D.A., Grybeck, Donald, Robinson, M.S., S mith, T.E., Yeend, Warren, and 54 contributors, 1987, Significant metalliferous lode deposits and placer districts of Alaska: U.S. Geological Survey Bulletin 1786, 2 plates, scale 1:5,000,000, 104 p. -1988, Metallogeny and major mineral deposits of Alaska: U.S. Geological Survey Open-File Keport $88-73,2$ plates, scale 1:5,000,000, 92 p. 
Ovenshine, A.T., and Brew, D.A., 1972, Separation and history of the Chatham Strait fault, southeast Alaska: 24th International Geological Congress, Montreal, Quebec, Canada, 1972, Proceedings, Section 3, p. 245-254.

Overstreet, W.D., 1967, The geologic occurrence of monazite: U.S. Geological Survey Professional Paper 530, 327 p.

Smith, P.S., 1933, Mineral industry of Alaska in 1931: U.S. Geological Survey Bulletin 844-A, p. 1-82. 1942, Occurrences of molybdenum minerals in Alaska: U.S. Geological Survey Bulletin 926-C, p. 161-210.

Sonnevil, R.A., 1981, The Chilkat-Prince of Wales plutonic province, southeastern Alaska, in Albert, N.R.D., and Hudson, T., eds., The United States Geological Survey in Alaska: Accomplishments during 1979: U.S. Geological Survey Circular 823B, p. B112-B115.

Taylor, H.P., Jr., 1967, The zoned ultramafic complexes of southeastem Alaska, in Wyllie, P.J., ed., Ultramafic and related rocks: New York, John Wiley and Sons, p. 97-120.

Taylor, H.P., Jr., and Noble, J.A., 1969, Origin of magnetite in the zoned ultramafic complexes of southeastern Alaska, in Wilson, H.D.B., ed., Magmatic ore deposits: Economic Geology Monograph 4, p. 209-230.

Tripp, R.B., and Cathrall, J.B., 1984, Mineralogical map showing the distribution of selected minerals in nonmagnetic fraction of heavy-mineral concentrates from stream sediments, Petersburg area, southeast Alaska: U.S. Geological Survey Open-File Report 83-420-X, scale 1:250,000, 1 sheet.

Twenhofel, W.S., Reed, J.S., and Gates, G.O., 1949, Some mineral investigations in southeastern Alaska: U.S. Geological Survey Bulletin 963-A, p. 1-45.

Twenhofel, W.S., Robinson, G.D., and Gault, H.R., 1946, Molybdenite investigations in southeastern Alaska: U.S. Geological Survey Bulletin 947-B, p. 7-38.

U.S. Bureau of Mines and U.S. Geological Survey, 1980, Principles of a resource/reserve classification for minerals: U.S. Geological Survey Circular 831, 5 p.

U.S. Geological Survey, 1979a, Aeroradioactivity map of Kosciusko Island, Alaska: U.S. Geological Survey Open-File Report 79-831, 1 sheet, scale 1:63,360. -1979b, Aeromagnetic map of the Petersburg area, Alaska: U.S. Geological Survey Open-File Report 79-832, 1 sheet, scale 1:250,000.

Wahrhaftig, Clyde, 1965, Physiographic divisions of Alaska: U.S. Geological Survey Professional Paper 482,52 p., 6 plates.

Walton, M.S., 1951, The Blashke Island ultrabasic complex with notes on related areas in southeastern Alaska: U.S. Geological Survey open-file report (informal no.126), $266 \mathrm{p}$.

Wedow, Helmuth, Jr., and others, 1953, Preliminary summary of reconnaissance for uranium and thorium in Alaska, 1952: U.S. Geological Survey Circular 248, $15 \mathrm{p}$.

White, M.G., and others, 1952, Preliminary summary of reconnaissance for uranium in Alaska, 1952: U.S. Geological Survey Circular 196, 17 p.

Wright, F.E., and Wright, C.W., 1905, Economic developments in southeastern Alaska: U.S. Geological Survey Bulletin 259, p. 47-68.

1908, The Ketchikan and Wrangell mining districts, Alaska: U.S. Geological Survey Bul rtin 347,210 p. 
APPENDIX A. CLASSIFICATION OF MINERAL RESOURCES AND GLOSSARY OF MINERAL RESOURCE TERMS USED BY THE U.S. BUREAU OF MINES AND U.S. GEOLOGICAL SURVTY (1980).

\begin{tabular}{|c|c|c|c|}
\hline \multirow{3}{*}{$\begin{array}{l}\text { Cumulative } \\
\text { Production }\end{array}$} & \multicolumn{2}{|c|}{ IDENTIFIED RESOURCES } & UNDISCOVERED RESOURCES \\
\hline & Demonstrated & \multirow[t]{2}{*}{ Inferred } & Probability Range \\
\hline & Measured & & Hypothetical \\
\hline ECONOMIC & Reserves & Inferred Reserves & \\
\hline $\begin{array}{l}\text { MARGINALLY } \\
\text { ECONOMIC }\end{array}$ & Marginal Reserves & $\begin{array}{l}\text { Inferred Marginal } \\
\text { Reserves }\end{array}$ & \\
\hline SUBECONOMIC & $\begin{array}{c}\text { Demonstrated } \\
\text { Subeconomic Resources }\end{array}$ & $\begin{array}{l}\text { Inferred Subeconomic } \\
\text { Resources }\end{array}$ & \\
\hline $\begin{array}{l}\text { Other } \\
\text { Occurrences }\end{array}$ & \multicolumn{3}{|c|}{ Includes nonconventional and low-grade materials } \\
\hline
\end{tabular}

\section{RESOURCE/RESERVE DEFINITIONS}

A dictionary definition of resource, "something in reserve or ready if needed," has been adapted for mineral and energy resources to comprise all materials, including those only surmised to exist, that have present or anticipated future value.

Resource.--A concentration of naturally occurring solid, liquid, or gaseous material in or on the Earth's crust in such form and amount that economic extraction of a commodity from the concentration is currently or potentially feasible.

Original Resource.--The amount of a resource before production.

Identified Resources.--Resources whose location, grade, quality, and quantity are known or estimated from specific geologic evidence. Identified resources include economic, marginally economic, and subeconomic components. To reflect varying degrees of geologic certainty, these economic divisions can be subdivided into measured, indicated, and inferred.

Demonstrated.--A term for the sum of measured plus indicated.

Measured.--Quantity is computed from dimensions revealed in outcrops, trenches, workings, or drill holes; grade and(or) quality are computed from the results of detailed sampling. The sites for inspection, sampling, and measurement are spaced so closely and the geologic character is so well defined that size, shape, depth, and mineral content of the resource are well established.

Indicated.--Quantity and grade and(or) quality are computed from information similar to that used for measured resources, but the sites for inspection, sampling, and measurement are farther apart or are otherwise less adequately spaced. The degree of assurance, although lower than that for measured resources, is high enough to assume continuity between points of observation.

Inferred.--Estimates are based on an assumed continuity beyond measured and(or) indicated resources, for which there is geologic evidence. Inferred resources may or may not be supported by samples or measurements.
Economic.--This term implies that profitable ext-action or production under defined investment assumptions has been established, analytically demonstrated, or assumed with reasonable certainty.

Subeconomic Resources.--The part of identified resources that does not meet the economic crit ria of reserves and marginal reserves.

Undiscovered Resources.--Resources, the existence of which are only postulated, comprising deposits that are separate from identified resources., Undiscnvered resources may be postulated in deposits of suct grade and physical location as to render them economic, marginally economic, or subeconomic. To reflect varying degrees of geologic certainty, undiscovered resources may be divided into two parts:

Hypothetical resources.--Undiscovered res?urces that are similar to known mineral bodies and that may be reasonably expected to exist in the same producing district or region under analogous geologic conditions. If exploration confirms their existence and reveals enough information about their quality, grade, and quantity, they vill be reclassified as identified resources.

Speculative Resources.--Undiscovered res?urces that may occur either in known types of deposits in favorable geologic settings where nineral discoveries have not been made, or in types of deposits as yet unrecognized for their economic potential. If exploration confirms their ex stence and reveals enough information about their quantity, grade, and quality, they will be reclassified as identified resources. 


\section{APPENDIX B. CLASSIFICATION OF MINERAL DEPOSITS}

(Modified from Nokleberg and others (1988) with additions from original sources cited in that compilation.)

Metalliferous lode deposits in this report are classified into 17 types, which are described below. This classification of mineral deposits is derived mainly from the mineral-deposit models developed by various specialists and compiled in Cox and Singer (1986) and to a lesser degree from the models in the prior compilations of Erickson (1982) and Cox (1983a,b). In addition, two of the mineral-deposit models used here were developed for use in Alaska by Nokleberg and others (1988). They are the metamorphosed sulfide and felsic-plutonic uranium models. The deposit types are listed in the same orter as they are listed in Cox and Singer (1986).

\section{GABBROIC Ni-Cu DEPOSIT}

(Adapted from synorogenic-synvolcanic Ni-Cu deposit of Norman J Page in Cox and Singer, 1986, p. 28, by Nokleberg and others, 1988, p. 6)

This deposit type consists of massive lenses and disseminated sulfides in small- to medium-size gabbroic intrusions in metamorphic belts of metasedimentary and metavolcanic rocks. In most areas of Alaska the depositional environment consists of post-metamorphic intermediate-level intrusions of norite, gabbronorite, and ultramafic rocks. Common minerals include pyrrhotite, pentlandite, and chalcopyrite, sometimes with pyrite; Ti- or Cr-magnetite; and PGE minerals and alloys. Accessory cobalt minerals also occur in some deposits. Notable examples of gabbroic Ni-Cu deposits in Alas'a are the Funter Bay, Brady Glacier, Bohemia Basin, and Mirror Harbor deposits, all in southeastem Alaska.

\section{ZONED MAFIC-ULTRAMAFIC Cr-Pt $( \pm \mathrm{Cu}, \mathrm{Ni}, \mathrm{Co}, \mathrm{Ti}$, or $\mathrm{Fe})$ DEPOSIT}

(Adapted from Alaskan PGE deposit type of Norman J Page and Floyd Gray

in Cox and Singer, 1986, p. 49, by Nokleberg and others, 1988, p. 6)

This deposit type consists of crosscutting ultramafic to mafic plutons that have approximately concentric zonira and contain chromite, native PGE, PGE minerals and alloys, and Ti-V magnetite. In most areas of Alaska, the emplac ?ment environment consisted of postmetamorphic and postdeformational, intermediate-level intrusion of mafic and (or) ultrimafic plutons. Common minerals include combinations of chromite, PGE minerals and alloys, pentlandite, pyrrhotite, Ti-V magnetite, bomite, and chalcopyrite. Notable examples are the Kemuk Mountain deposit in west-central Alaska, the Union Bay, Duke Island, and Klukwan deposits, and the Salt Chuck mine, all in southeastem Alaska.

\section{CARBONATTTE DEPOSIT}

(Adapted from Donald A. Singer, in Cox and Singer, 1986, p. 51, for this report)

This deposit type consists of a variety of rare-earth-element (REE)-bearing and other carbonate minerals in and associated with carbonatite dikes, sills, breccias, sheets, veins, and large masses. The depositional environm?nt is interpreted to be any associated with multiple stages of igneous, deuteric, and metasomatic crystallization in carbcnatite magma. Tectonically, most carbonatite deposits are on continental shields and are associated with fault lineaments and(or) alkaline volcanism. A wide variety of minerals may be present, including the common minerals barite, strontianite \pm siderite \pm rhodochrosite \pm ankerite \pm bastnaesite \pm chlorites, together with chalcopyrite, pyrite, sphalerite, \pm galen a and other minerals in the REE-bearing carbonatites. Alteration is commonly fenitization and, locally, chloritization. Nokleberg and others (1988) did not recognize any carbonatite deposits in Alaska; we consider it possible that both the Salmon Bay and Cornwallis Peninsula occurrences are of this type, however.

\section{Sn GREISEN, Sn VEIN, and Sn SKARN DEPOSITS}

(Adapted from Bruce L. Reed and Dennis P. Cox, in Cox and Singer, 1986, p. 58, 61, 67, by Nokleberg and others, 1988, p. 5)

These three deposit types commonly occur in the same area and sometimes grade into one another. The Sn greisen deposit type consists of disseminated cassiterite, cassiterite-bearing veinlets, and $\mathrm{Sn}$ sulfosalts in stockworks, lenses, pipes, and breccia in greisenized granite, mainly biotite and (or) muscovite leucogranite emplaced in a mesozonal tc deep volcanic environment. Sn greisens are generally associated with late-stage, fractionated granitic magmas. Asso-iated minerals include molybdenite, arsenopyrite, beryl, scheelite, and wolframite. Alteration minerals consist of incipi nt to massive replacement quartz, muscovite, tourmaline, and fluorite. Notable examples are the Kougarok deposit on the Saward Peninsula and the Coal Creek deposit in southern Alaska.

The Sn vein deposit type consists of simple to complex fissure fillings or replacement lodes in or near felsic plutonic rocks, mainly mesozonal to hypabyssal plutons, commonly with dike swarms. The deposits tend to occur wit ${ }^{h}$ in or above the apices of granitic cusps and ridges. The deposit minerals are extremely varied and include cassiterite, wolframite, 
arsenopyrite, molybdenite, scheelite, and beryl. Alteration minerals consist of sericite, tourmaline, quartz, chlorite, and hematite. The one possible example is the Lime Peak deposit in east-central Alaska.

The Sn skarn deposit type consists of $\mathrm{Sn}, \mathrm{W}$, and Be minerals in skarns, veins, stockworks, and greisen near intrusive contacts between epizonal(?) granitic plutons and limestone. The deposit minerals include cassiterite, sometimes with scheelite, sphalerite, chalcopyrite, pyrrhotite, magnetite, and fluorite. Alteration consists of greisen near granite marrins and metasomatic development of andradite, idocrase, amphibole, chlorite, chrysoberyl, and mica in skarn. The notable example is the Lost River mine on the Seward Peninsula.

\section{$\mathrm{Cu}-\mathrm{Zn}-\mathrm{Pb}( \pm \mathrm{Au}, \mathrm{Ag}), \mathrm{W}$, and $\mathrm{Fe}( \pm \mathrm{Au})$ SKARN DEPOSITS}

(Adapted from Dennis P. Cox and Theodore G. Theodore

in Cox and Singer, 1986, p. 86, 90, 94, by Nokleberg and others, 1988, p. 5)

$\mathrm{Cu}-\mathrm{Zn}-\mathrm{Pb}$ skarn deposit type consists of chalcopyrite, sphalerite, and galena in calc-silicate skarns that replace carbonate rocks along intrusive contacts with quartz diorite to granite and diorite to syenite plutons. Zn-Pb-rich skarns tend to occur farther from the intrusion; $\mathrm{Cu}$ - and $\mathrm{Au}$-rich skarns tend to occur closer to the intrusion. The depositional environment is mainly calcareous sedimentary sequences intruded by felsic to intermediate granitic plutons. Associated minerals include pyrite, hematite, magnetite, bornite, arsenopyrite, and pyrrhotite. Metasomatic replacements consist of a wide variety of calc-silicate and related minerals. Notable examples of $\mathrm{Cu}-\mathrm{Zn}-\mathrm{Pb}$ skarn deposits are the Bowser Creek. Rat Fork, Sheep Creek, and Tin Creek deposits. Notable examples of $\mathrm{Cu}$-Au and Au skarn deposits in Alaska are the Nixon FrkMedfra mine in west-central Alaska and the Jumbo mine in southeastern Alaska.

The W skarn deposit type consists of scheelite in calc-silicate skarns that replace carbonate rocks along or near intrusive contacts with quartz diorite to granite plutons. The depositional environment is along contacts and in roof pendants of batholiths and in thermal aureoles of stocks that intrude carbonate rocks. Associated minerals are molybdenite, pyrrhotite, sphalerite, chalcopyrite, bornite, pyrite, and magnetite. Metasomatic replacements consist of a wide variety of calc-silicate and related minerals. Notable examples are the deposits and mines in the Gilmore Dome area of the Fairbanks district in east-central Alaska.

The Fe skarn deposit type consists of magnetite and (or) Fe sulfides in calc-silicate skarns that replace carbc nate rocks or calcareous clastic rocks along intrusive contacts with dicrite, granodiorite, granite, and coeval volcanic rocks. The depositional environment is along intrusive contacts. The chief associated mineral is chalcopyrite. Metasomatic replacements consist of a wide variety of calc-silicate and related minerals. Notable examples are the Medfra deposit in vestcentral Alaska, the Nabesna and Rambler mines in southern Alaska, and the Kasaan Peninsula mine in southeastern Alasl a..

\section{PORPHYRY Cu-Mo, PORPHYRY Cu, AND PORPHYRY Mo DEPOSITS}

(Adapted from Dennis P. Cox and Theodore G. Thcodore, in Cox and Singer, 1986, p. 115, 120, by Nokleberg and others, 1988, p. 5-6)

The porphyry Cu-Mo deposit type consists of stockwork veinlets of quartz, chalcopyrite, and molybdenite in or near porphyritic intermediate to felsic intrusion. The intrusions occur mainly as stocks and breccia pipes that intrude batholithic, volcanic, or sedimentary rocks. The depositional environment is high-level intrusive porphyries that are contemporaneous with abundant dikes, faults, and breccia piles. Associated minerals include pyrite and peripl sral sphalerite, galena, and gold. Alteration minerals consist of quart7, K-feldspar, and biotite or chlorite. Notable exampler are the Taurus deposit in east-central Alaska, the Orange Hill, Bond Creek, Baultoff, Horsfeld, Carl Creek deposits in southern Alaska, and the Pyramid deposit in the Alaska Peninsula.

The porphyry $\mathrm{Cu}$ deposit type consists of chalcopyrite in stockwork veinlets in hydrothermally altered porphyry and adjacent country rock. The porphyries range in composition from tonalite to monzogranite to syenitic porphyry. The depositional environment is epizonal intrusive rocks with abundant dikes, breccia pipes, cupolas of batholiths, and faults. Associated minerals are pyrite, molybdenite, magnetite, and bomite. Alteration consists of sodic, potassic, phy'lic, argillic, and propylitic types. An example is the Margerie deposit in southeastern Alaska.

The porphyry Mo deposit type consists of quartz-molybdenite stockwork veinlets in granitic porphyry and adj^cent country rock. The porphyries range in composition from tona'ite to granodiorite to monzogranite. The depositional environment is epizonal. Associated minerals are pyrite, scheelite, chalcopyrite, and tetrahedrite. Alteration is potassic grading outward to propylitic, sometimes with phyllic and argillic overprint. Notable examples are the Bear Mountain deposit in the northeastern Brooks Range, and the Quartz Hill deposit in southeastern Alaska.

\section{POLYMETALLIC VEIN DEPOSIT}

(Adapted from Dennis P. Cox, in Cox and Singer, 1986, p. 125, by Nokleberg and others, 1988, p. 4) 
This deposit type consists of quartz-carbonate veins, often with silver and gold, and associated base-metal su'fides. The veins are related to hypabyssal intrusions in sedimentary and metamorphic terranes or to metamorphic fluids forming during waning regional metamorphism. The associated intrusions range in composition from calcalkaline to alkalire and occur in dike swarms, hypabyssal intrusions, and small to moderate-size, intermediate to felsic plutons, locally assoriated with andesite to rhyolite flows. The depositional environment is near-surface fractures and breccias within thermal aureoles of small to moderate-size intrusions, including within the intrusions. The deposit minerals include native gold, elertrum, pyrite, and sphalerite, sometimes with chalcopyrite, galena, arsenopyrite, tetrahedrite, $\mathrm{Ag}$ sulfosalts, and argentite. Alteration consists of wide propylitic zones and narrow sericitic and argillic zones. Notable examples are the Indeperdence and Golden Horn mines, and the Broken Shovel and Beaver Creek deposits in west-central Alaska, the Quigley Ridge, Banjo, Spruce Creek, and Stampede deposits in the Kantishna district of east-central Alaska, the Cleary Summit and Ester Dome mines in the Fairbanks district of east-central Alaska, the Sedanka and Bonanza Hills deposits of the Alaska Peninsul-, and the Golden Zone deposit of southern Alaska.

\section{FELSIC PLUTONIC U DEPOSIT}

(Adapted from Nokleberg and others, 1988, p. 6, for this report)

This deposit type consists of disseminated $\mathrm{U}, \mathrm{Th}$, and REE minerals in fissure veins and alkalic granite dikes in or along the margins of alkalic and peralkalic granitic plutons or in granitic plutons, including granite, alkalic granite, granodiorite, syenite, and monzonite. The depositional environment is mainly the margins of epizonal to mescronal granitic plutons. Common minerals include allanite, thorite, uraninite, bastnaesite, monazite, uranothorianite, and xenotime, sometimes with galena and fluorite. Notable examples are the Mount Prindle deposit in east-central Alasla and the Bokan Mountain deposits in southeastern Alaska.

\section{CYPRUS MASSIVE SULFIDE DEPOSIT}

(Adapted from Donald A. Singer, in Cox and Singer, 1986, p. 131, by Nokleberg and others, 1988, p. $2-3$ )

This deposit type consists of massive sulfides in pillow basalt. The depositional environment consirts of submarine hot springs along an axial graben in oceanic or back-arc spreading ridges, or hot springs related to subrarine volcanoes in seamounts. Common minerals are pyrite, chalcopyrite, sphalerite, and lesser marcasite and pyrrhotite. The sulfides occur in pillow basalts that are associated with tectonized dunite, harzburgite, gabbro, sheeted diabase diker, and fine-grained sedimentary rocks, all part of an ophiolite assemblage. Beneath the massive sulfides in places is strin -er or stockwork pyrite, pyrrhotite, minor chalcopyrite, and sphalerite. The sulfide minerals are locally brecciated and recem anted. Alteration in the stringer zone consists of abundant quartz, chalcedony, chlorite, and some illite and calcite. Some denosits are overlain by Fe-rich and Mn-poor ochre. Notable examples are the Knight Island and Threeman mines, and the Copper Bullion deposit, all in coastal southern Alaska.

\section{BESSHI MASSIVE SULFIDE DEPOSIT}

(Adapted from Dennis P. Cox, in Cox and Singer, 1986, p. 136, by Nokleberg and others, 1988, p. 2)

This deposit type consists of thin, sheetlike bodies of massive to well-laminated pyrite, pyrrhotite, and chalcopyrite, and other less abundant sulfide minerals, within thinly laminated clastic sedimentary rocks and mafic tuff: The rock types are mainly marine clastic sedimentary rocks, basaltic and lesser andesitic tuff and breccia, and local black shale and red chert. The depositional environment is uncertain, but may possibly be submarine hot springs related to submarine basaltic volcanism. Associated minerals include sphalerite and lesser magnetite, galena, bornite, and tetrahedrite. with gangue quartz, carbonate, albite, white mica, and chlorite. Alteration is sometimes difficult to recognize becarse of metamorphism. Notable examples are the Midas, Latouche, Beatson, Ellamar, and Fidalgo-Alaska mines in the Prince William Sound region of southern Alaska.

\section{EPITHERMAL VEIN DEPOSIT}

(Adapted from Dan L. Mosier, Takeo Sato, Norman J. Page, Donald A. Singer, and Byron R. Berger, in Cox and Singer, 1986, p. 145, 150, 154, by Nokleberg and others, 1988 , p. 4)

This deposit type consists of quartz-carbonate-pyrite veins with a wide variety of minerals, including gold, silver sulfosalts, chalcopyrite, argentite, galena, sphalerite, and arsenopyrite. The veins occur in felsic to intermediate volcanic rocks, sometimes overlying older volcanic sequences or igneous intrusions. One class of epithermal vein deposits such as those at Creede, Colorado, has high $\mathrm{Pb}, \mathrm{Zn}$, and $\mathrm{Ag}$, sometimes high $\mathrm{Cu}$, and low $\mathrm{Au}$; another class, such as those at $\mathrm{Sado}$, Japan, has high $\mathrm{Au}$, moderate to low $\mathrm{Ag}$, sometimes high $\mathrm{Cu}$, and generally low $\mathrm{Pb}$ and $\mathrm{Zn}$ concentrations. For both groups, the host volcanic rock composition ranges from andesite to rhyolite. The depositional environment is intermediate to felsic 
volcanic arcs and centers. Associated minerals include electrum, chalcopyrite, copper and silver sulfosalts, with lesrer tellurides and bomite. Alteration minerals include quartz, kaolinite, montmorillonite, illite, and zeolites. Notable examp'ss are the Aquila and Shumagin deposits, and the Apollo-Sitka mine on the Alaska Peninsula.

\section{KUROKO MASSIVE SULFIDE DEPOSTT}

(Adapted from Donald A. Singer, in Cox and Singer, 1986, p. 189, by Nokleberg and others, 1988, p. 2, and further modified for this report)

This deposit type consists of volcanogenic, massive to disseminated sulfides that occur in felsic to intermedinte marine volcanic and pyroclastic rocks and interbedded sedimentary rocks. The volcanic rocks are mainly rhyolite and dacite with subordinate basalt and andesite. The depositional environment is mainly hot springs related to marine volcanism in island-arc or in extensional regimes. Common minerals include pyrite, chalcopyrite, sphalerite, barite, and lesser galena, tetrahedrite, tennantite, and magnetite. Local alteration to zeolites, montmorillonite, silica, chlorite, and sericite may occur. Notable examples are the Arctic, Smucker, and Sun deposits in the Brooks Range, the WTF, Red Mountain deposits, and Delta district deposits in east-central Alaska, and the Greens Creek, Glacier Creek, Khayyam, and Orange Point deporits in southeastern Alaska.

The Medford deposit type is generally similar to the Kuroko, but consists of smaller tonnage bodies in lower Pal ozoic and Mesozoic rocks.

\section{SANDSTONE U DEPOSIT}

(Adapted from Christine Turner Peterson and Carroll A. Hodges

in Cox and Singer, 1986, p. 209, by Nokleberg and others, 1988, p. 3)

This deposit type consists of concentrations of $U$ oxides and related uranium minerals in localized, reduced environments in medium- to coarse-grained feldspathic or tuffaceous sandstone, arkose, mudstone, and conglomerate. The depositional environment is continental basin margins, fluvial channels, fluvial fans, or stable coastal plain, sometines with nearby felsic plutons or felsic volcanic rocks. Common minerals include pitchblende, coffinite, carnotite, and pyrite. A notable example is the Death Valley deposit in west-central Alaska.

\section{SEDIMENTARY EXHALATIVE Zn-Pb DEPOSIT}

(Adapted from Joseph A. Briskey, in Cox and Singer, 1986, p. 211, by Nokleberg and othe $s_{1}, 1988$, p. 3)

This deposit type consists of stratiform, massive to disseminated sulfides in sheetlike or lenslike tabular bodies that are interbedded with euxinic marine sedimentary rocks, including dark shale, siltstone, limestone, chert, and sandstone. The depositional environment consists mainly of marine epicratonic embayments and intracratonic basins, with smaller lo :al restricted basins. Common minerals include pyrite, pyrrhotite, sphalerite, galena, barite, and chalcopyrite. Extensive alteration may occur, including stockwork and disseminated sulficies, silica, albite, and chlorite. Notable examples are the Lik and Red Dog Creek dèposits in the northwestern Brooks Range.

\section{BEDDED BARITE DEPOSIT}

(Adapted from Greta J. Orris, in Cox and Singer, 1986, p. 216, by Nokleberg and others, 1988, p. 3, and further modified for this report)

This deposit type consists of stratiform, massive barite interbedded with marine cherty and calcareous sediment ryy rocks, mainly dark chert, shale, mudstone, and dolomite, but also with quartzite, argillite, and greenstone. The depositional environment consists of epicratonic marine basins or embayments, often with smaller local basins. The local association of bedded barite deposits associated with sedimentary exhalative $\mathrm{Zn}-\mathrm{Pb}$ or Kuroko massive sulfide deposits (described above) suggests that deposits may also form in extensional and island-arc environments. Alteration consists of secondary ba-ite veining and local, weak to moderate sericite replacement. Associated minerals include minor witherite, pyrite, galena, and sphalerite Notable examples are the Nimiuktuk deposit in the nortiwestern Brooks Range and the Castle Island mine. in southeastern Alaska.

\section{LOW-SULFIDE Au-QUARTZ VEIN DEPOSTT}

(Adapted from Byron R. Berger, in Cox and Singer, 1986, p. 239, by Nokleberg and others, 1988, p. 4)

This deposit type, abbreviated to "Au-quartz vein" in the descriptions, consists of gold in massive, persistent quartz veins in regionally metamorphosed volcanic rocks, metamorphosed graywacke, chert, and shale. The depositional 
environment is low-grade metamorphic belts. The veins are generally late synmetamorphic to postmetamorphic and 1 rcally cut granitic rocks. Associated minerals are minor pyrite, galena, sphalerite, chalcopyrite, arsenopyrite, and pyrrhotite. Alteration minerals include quartz, siderite, albite, and carbonate. Notable examples are the Big Hurrah mine on the Saward Peninsula, the Chandalar district mines in the southern Brooks Range, the Willow Creek district mines, the Nukr Bay, Monarch, Jewel, Granite, and Cliff mines in southern Alaska, and the Alaska-Juneau, Jualin, Kensington, Sumdum Chief, Treadwell, Nido, and Chichagoff mines in southeastern Alaska.

\section{METAMORPHOSED SULFIDE DEPOSIT}

(Adapted from Nokleberg and others, 1988, p. 3, for this report)

This deposit type consists of stratabound, massive to disseminated sulfides hosted in moderately to highly metamorphosed and deformed metavolcanic or metasedimentary rocks. Metamorphism and deformation have ob-cured protoliths of host rocks and deposits so as to preclude classification into more specific deposit types. The interpreted host rocks for these deposits are mainly felsic to mafic metavolcanic rocks and metasedimentary or metavolcanic schist and gneiss. Common minerals include chalcopyrite, sphalerite, galena, and bornite, sometimes with pyrite, magnetita. and hematite. Alteration is usually difficult to recognize because of metamorphism. These deposits occur mainly in the regional metamorphic rocks in southeastern Alaska in either the Coast plutonic-metamorphic complex or the Alexander belt. $\mathrm{N}^{\prime}$ (ntable examples are the Sweetheart Ridge, Sumdum, and Moth Bay deposits, all in southeastern Alaska. 
APPENDIX C. ABBREVIATIONS USED IN THIS REPORT.

\begin{tabular}{|c|c|}
\hline Symbol & Chemical Element(s) \\
\hline $\mathrm{Ag}$ & Silver \\
\hline As & Arsenic \\
\hline Au & Gold \\
\hline $\mathrm{Ba}$ & Barium \\
\hline $\mathrm{Be}$ & Beryllium \\
\hline $\mathbf{B i}$ & Bismuth \\
\hline Co & Cobalt \\
\hline $\mathrm{Cr}$ & Chromium \\
\hline $\mathrm{Cu}$ & Copper \\
\hline $\mathbf{F}$ & Fluorine \\
\hline $\mathrm{Fe}$ & Iron \\
\hline $\mathrm{La}$ & Lanthanum \\
\hline Mo & Molybdenum \\
\hline $\mathrm{Nb}$ & Niobium \\
\hline $\mathrm{Pb}$ & Lead \\
\hline $\mathrm{Pt}$ & Platinum \\
\hline RA & Radioactive elements \\
\hline REE & Rare-earth elements \\
\hline $\mathrm{Sb}$ & Antimony \\
\hline $\mathrm{Sn}$ & Tin \\
\hline $\mathrm{Sr}$ & Strontium \\
\hline Th & Thorium \\
\hline $\mathrm{Ti}$ & Titanium \\
\hline $\mathrm{U}$ & Uranium \\
\hline $\mathrm{V}$ & Vanadium \\
\hline w & Tungsten \\
\hline $\mathbf{Y}$ & Yttrium \\
\hline $\mathrm{Zn}$ & Zinc \\
\hline
\end{tabular}


$\bullet$

i 